Prace Komisji Geografii Komunikacji PTG

Transport Geography Papers of Polish Geographical Society

$20(3) / 2017$

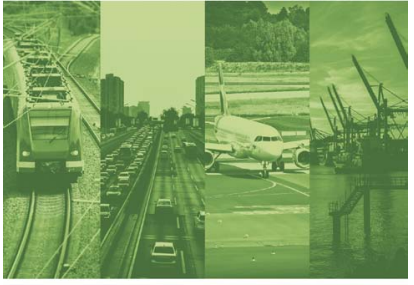

\section{Prace Komisji Geografii Komunikacji PTG}

$2017,20(3), 7-30$

DOI 10.4467/2543859XPKG.17.013.7487

\title{
KIERUNKI MODERNIZACJI SIECI KOLEJOWEJ W POLSCE
}

\section{Directions of railway network modernization in Poland}

\author{
Stanisław Koziarski \\ Katedra Ochrony Powierzchni Ziemi, Wydział Przyrodniczo-Techniczny, Uniwersytet Opolski, Oleska 48, 45-052 Opole \\ e-mail: stanislaw.koziarski@uni.opole.pl
}

Cytacja:

Koziarski S., 2017, Kierunki modernizacji sieci kolejowej w Polsce, Prace Komisji Geografii Komunikacji Polskiego Towarzystwa Geograficznego, 20(3), 7-30.

\begin{abstract}
Streszczenie: Opracowanie przedstawia kierunki modernizacji sieci kolejowej Polski w latach 2003-2017. Długość sieci kolejowej w kraju ulega zmniejszeniu. Zachodzi proces likwidacji linii i zawieszenia przewozów kolejowych. W kraju modernizowane są główne linie magistralne. Na modernizację składają się: wymiana torów, przebudowa trakcji elektrycznej i wprowadzenie nowoczesnych systemów sterowania ruchem i sygnalizacji (ECTS). Przebudowie ulęgają linie kolejowe o znaczeniu tranzytowym zaliczane do europejskiego układu połączeń kolejowych w ruchu pasażerskim (umowa AGC) i towarowym (umowa AGTC). Projekty modernizacji linii kolejowych są finansowane ze środków europejskich i krajowych. Główne źródła finansowania inwestycji transportowych to fundusze europejskie takie jak: Connecting Europe Facility (CEF), Program Operacyjny Infrastruktura i Środowisko (POliŚ), Program Operacyjny Polska Wschodnia (PO PW) i Regionalne Programy Operacyjne (RPO).
\end{abstract}

Słowa kluczowe: Polska, sieć kolejowa, inwestycje, modernizacja linii, finansowanie, projekty transportowe

Abstract: This article discusses the modernization of Poland's rail network in 2004-2016. The length of the railway network in the country is decreasing. There is a process of liquidation of lines and suspension of rail transport. Main railway lines are modernized in the country. Modernization consists of replacement of tracks, reconstruction of electrical traction and introduction of modern traffic control and signaling systems (ECTS). Reconstruction of railways of transit importance is included in the European rail system for passenger traffic (AGC) and goods (AGTC). Railway modernization projects are financed by European and national funds. The main sources of funding for transport investments are European funds such as Connecting Europe Facility (CEF), Operational Program Infrastructure and Environment (POliŚ), Operational Program Eastern Poland (PO PW) and Regional Operational Programs (RPO).

Key words: Poland, railway network, investments, modernization of lines, financing, railway transport projects

Otrzymano (Received): 26.04.2017

Zaakceptowano (Accepted): 19.09.2017 


\section{Wstęp}

Celem opracowania jest przedstawienie stanu i kierunków modernizacji sieci kolejowej w Polsce, po akcesji kraju do struktur europejskich w 2004 r. Inwestycje, zwłaszcza z zakresu elektryfikacji trakcji kolejowej prowadzono w kraju praktycznie tylko do 1989 r., kiedy to nastąpiły zmiany ustrojowe w kraju. Upadek przemysłu ciężkiego spowodował załamanie przewozów towarowych, głównego źródła dochodów ówczesnego przedsiębiorstwa PKP. Rozpoczął się proces likwidacji nierentownych linii kolejowych. Doszło do podziału przedsiębiorstwa PKP na niezależne spółki. Proces inwestycyjny i odtworzeniowy infrastruktury transportu kolejowego uległ załamaniu. Proces spadku przewozów kolejowych połączony z dekapitalizacją jej majątku trwał praktycznie do chwili integracji Polski z UE. Polityka transportowa Unii Europejskiej uwzględniająca rozwój zrównoważony transportu przywróciła powtórnie znaczenie linii kolejowych. Zaczęto przywracać zachwiane na korzyść transportu samochodowego proporcje zwłaszcza w zakresie inwestycji infrastrukturalnych prośrodowiskowego transportu kolejowego. Od 2004 r. rozpoczął się ponowny proces modernizacji sieci kolejowej Polski. Początkowo w niewielkim zakresie, by po 2010 r. ulec znaczącemu przyśpieszeniu. Chociaż należy stwierdzić, że nie jest to nadal skala porównywalna z rozbudową krajowej sieci autostrad i dróg ekspresowych.

Analizy infrastruktury transportu kolejowego dokonano za lata 2000-2017, przy czym większość danych faktograficznych dotyczy okresu po 2004 r. i akcesji Polski do UE, kiedy to nastąpił znaczny wzrost nakładów na inwestycje liniowe. Zestawione w opracowaniu aktualne dane statystyczne odnoszą się w większości do 2016 r. i pochodzą z publikacji Głównego Urzędu Statystycznego Transport - wyniki działalności w 2016 r. Szczegółowe dane dotyczące inwestycji liniowych na sieci kolejowej zestawiono na podstawie danych PKP Polskie Linie Kolejowe (roczne raporty z działalności spółki), a także internetowego forum infrastruktury kolejowej Polski (www.skyscrapercity.com) i rynku kolejowego (www.rynekkolejowy.pl).

Przedsiębiorstwo PKP Polskie Linie Kolejowe jest podmiotem odpowiedzialnym za realizację polityki państwa w zakresie transportu kolejowego. Podstawowym zadaniem PLK jest utrzymanie i modernizacja sieci kolejowej. Działalność inwestycyjna Polskich Linii Kolejowych jako zarządcy państwowej infrastruktury kolejowej ma na celu wzrost sprawności i wydajności systemu transportowego kraju poprzez realizację programu modernizacji linii kolejowych. Głównymi założeniami modernizacji są dostosowanie linii kolejowych do parametrów opisanych w dwóch umowach: 1. AGC - wyznaczającej sieć linii kolejowych o znaczeniu międzynarodowym, które powinny być dostosowane do prędkości: $160 \mathrm{~km} / \mathrm{h}$ w ruchu pasażerskim i $120 \mathrm{~km} / \mathrm{h}$ w ruchu towarowym, przy nacisku osi 225 kN; 2. AGTC - określającej sieć linii kolejowych dla międzynarodowych przewozów kontenerowych transportem kolejowym oraz terminale kontenerowe położone na sieci kolejowej.

\section{Stan techniczny linii kolejowych}

W latach 1990-2016 następowało zmniejszenie długości eksploatowanych linii kolejowych w Polsce (tab. 1). Regres długości sieci kolejowej był następstwem zmniejszających się potrzeb przewozowych. Na koniec 2015 r. PKP Polskie Linie Kolejowe eksploatowały $18510 \mathrm{~km}$ linii kolejowych obejmujących łącznie $37076 \mathrm{~km}$ torów, w tym $27115 \mathrm{~km}$ torów szlakowych oraz 9103 km torów stacyjnych. Na sieci kolejowej zabudowanych było 39998 rozjazdów, w tym 17894 rozjazdów w torach szlakowych oraz 22094 w torach stacyjnych. Na skrzyżowaniach linii kolejowych z drogami w poziomie szyn eksploatowano 14889 przejazdów kolejowo-drogowych, w tym 2458 przejazdów kategorii A. Z pozostałych obiektów infrastruktury technicznej PLK eksploatowały: 25303 obiektów inżynieryjnych, w tym 6400 mostów i wiaduktów, 6160 budynków i 13129 innych budowli.

W wyniku prowadzonych sukcesywnie robót utrzymaniowych, naprawczych oraz inwestycyjnych na koniec 2015 r. długość torów linii kolejowych z dobrą oceną stanu technicznego stanowiła 54\%, dla porównania w 2012 r. - 43\% całkowitej długości torów. Przy określeniu stanu technicznego torów przyjęto następujące kryteria oceny dobrej - to linie kolejowe eksploatowane z założonymi parametrami, wymagające tylko robót konserwacyjnych. W latach 2001-2015 Polskie Linie Kolejowe prowadziły na podstawie rozkładów jazdy statystykę zwiększenia lub zmniejszenia prędkości na liniach. W wyniku remontów i prac utrzymaniowych uzyskiwano odcinki, na których zwiększano prędkość rozkładową oraz odcinki, na których na skutek dekapitalizacji i braku prac remontowych szybkość tę ograniczano. Bilans tych działań w dekadzie lat 2000-2010 był ujemny, tzn. przybywało linii, na których prędkość ograniczano, natomiast w okresie 2011-2015 dodatni, tzn. wzrastała długość linie, na których szybkość zwiększano. W 2001 r. zmniejszono prędkość na 1052 km linii, w 2002 r. - 306 km, w 2003 r. - 1803 km, w 2004 r. 2280 km, w 2005 r. - 1024 km, w 2006 r. - 1783 km, w 2007 r. -488 km, w 2008 r. -703 km, w 2009 r. 1002 km, w 2010 r. -830 km, w 2011 r. - 1557 km. Dodatni wynik bilansu uzyskano dopiero w 2011 r., gdy 
Tab. 1. Sieć kolejowa Polski w latach 2003-2016.

\begin{tabular}{|c|c|c|c|c|c|c|}
\hline Lata & $\begin{array}{l}\text { Linie kolejowe } \\
\qquad \mathbf{~ k m}\end{array}$ & $\begin{array}{c}\text { Gęstość sieci } \\
\text { kolejowej w km } \\
\text { na } 100 \text { km }^{2}\end{array}$ & $\begin{array}{l}\text { Linie zelektry- } \\
\text { fikowane } w \text { km }\end{array}$ & $\begin{array}{l}\text { Linie 1-torowe } \\
\quad \text { w km }\end{array}$ & $\begin{array}{l}\text { Linie 2-torowe } \\
\quad \text { w km }\end{array}$ & $\begin{array}{c}\text { Wąskotorowe } \\
\text { w km }\end{array}$ \\
\hline 2003 & 20665 & 6,5 & 12160 & 11425 & 8896 & 344 \\
\hline 2004 & 20250 & 6,5 & 12017 & 11114 & 8792 & 344 \\
\hline 2005 & 20253 & 6,5 & 11884 & 11096 & 8747 & 410 \\
\hline 2006 & 20176 & 6,5 & 11871 & 11096 & 8745 & 310 \\
\hline 2007 & 20107 & 6,4 & 11898 & 11052 & 8745 & 310 \\
\hline 2008 & 20196 & 6,5 & 11924 & 11269 & 8738 & 189 \\
\hline 2009 & 20360 & 6,5 & 11956 & 11432 & 8739 & 189 \\
\hline 2010 & 20228 & 6,5 & 11916 & 11353 & 8736 & 139 \\
\hline 2011 & 20228 & 6,5 & 11880 & 11387 & 8726 & 115 \\
\hline 2012 & 20094 & 6,4 & 11920 & 11262 & 8717 & 115 \\
\hline 2013 & 19328 & 6,2 & 11868 & 10560 & 8699 & 69 \\
\hline 2014 & 19240 & 6,2 & 11830 & 10623 & 8617 & . \\
\hline 2015 & 19231 & 6,2 & 11865 & 10505 & 8726 & . \\
\hline 2016 & 19132 & 6,2 & 11874 & 10401 & 8731 & . \\
\hline
\end{tabular}

Źródło: zestawienie własne na podstawie danych GUS (Transport - wyniki działalności za lata 2003-2016).

przewaga linii z podwyższoną prędkością osiągnęła wielkość 664 km, w 2012 r. - już 1064 km, w 2013 r. 842, w 2014 r. - 2114, a w 2015 r. - 1910 km1. Kolejne lata będą również korzystne $w$ tym zestawieniu, gdyż do eksploatacji zostaną przekazane linie, które poddano modernizacji wprowadzającej parametry unijne dla pociągów pasażerskich $(160 \mathrm{~km} / \mathrm{h})$ i towarowych (120 km/h) (ryc. 1). Głównymi przyczynami obniżania prędkości rozkładowych i wprowadzania lokalnych ograniczeń szybkości niezmiennie od lat są: zaległości w naprawach torów i obiektów inżynieryjnych (mosty, wiadukty, przepusty), wyeksploatowane podkłady i szyny o przekroczonym teoretycznie okresie użytkowania.

W wyniku prac modernizacyjnych zwiększenie szybkości pociągów następowało na wybranych fragmentach linii i obejmowało głównie odcinki torów zlokalizowane na szlakach poza stacjami; nadal ograniczenia prędkości obejmowały stacje, a zwłaszcza zamontowane tam tory i rozjazdy. Na przykład, w 2011 r. zwiększono szybkość pociągów m.in. na liniach: Warszawa - Błonie, Łowicz - Kutno, Łowicz Zgierz, Białystok - Łapy, Poznań - Leszno - Rawicz, Poznań - Inowrocław, Bydgoszcz - Tczew, Legnica Lubin - Rudna Gwizdanów, Olsztyn - Pieniężno, Rejowiec - Zamość i Pyskowice - Lubliniec. W 2010 r. długość torów z dopuszczalną prędkością rozkładową do 160 km/h objęła 1857 km, w 2012 r. - 1956 km, w 2014 r. - 2568 km, a w 2015 r. już 2813 km.

Dynamiczny proces komputeryzacji systemów automatyki i sterowania ruchem kolejowym (srk) oraz telekomunikacji umożliwił zastosowanie zaawansowanych technik mikroprocesorowych. W 2015 r. komputerowe systemy sterowania ruchem kolejowym zainstalowane były w 215 okręgach nastawczych, które sterują 4829 zwrotnicami i 5772 sygnalizatorami. Urządzenia zdalnego sterowania ruchem obejmują 1126 km linii kolejowych, 109 stacji oraz 31 centrów zdalnego srk. Bezpieczeństwo kursowania pociągów pomiędzy poszczególnymi stacjami zapewniają blokady liniowe. W 2015 r. były one zainstalowane na 15880 km linii kolejowych, przy czym 12708 km linii wyposażonych było w blokady jednoodstępowe, $3172 \mathrm{~km}$ - w samoczynne blokady wieloodstępowe, z czego $1245 \mathrm{~km}$ - to blokady komputerowe wyposażone w zintegrowane systemy zdalnej diagnostyki. Sygnalizatory stacyjne obsługiwane są w większości przez: przekaźnikowe (50\%), mechaniczne scentralizowane $(25 \%)$ lub komputerowe (12\%) urządzenia zabezpieczenia ruchu kolejowego (uzrk); przestarzałe mechaniczno-kluczowe obejmują jeszcze ok. 5\% uzrk $^{2}$.

Kilometraż linii ze zmianami prędkości zestawiono na podstawie Raportów rocznych PLK. Również większość szczegółowych danych przytoczonych w opracowaniu pochodzi z opracowań i oficjalnych komunikatów zamieszczonych na portalu internetowym PLK.

Dane liczbowe pochodzą z Raportu rocznego PLK za 2015 r. 


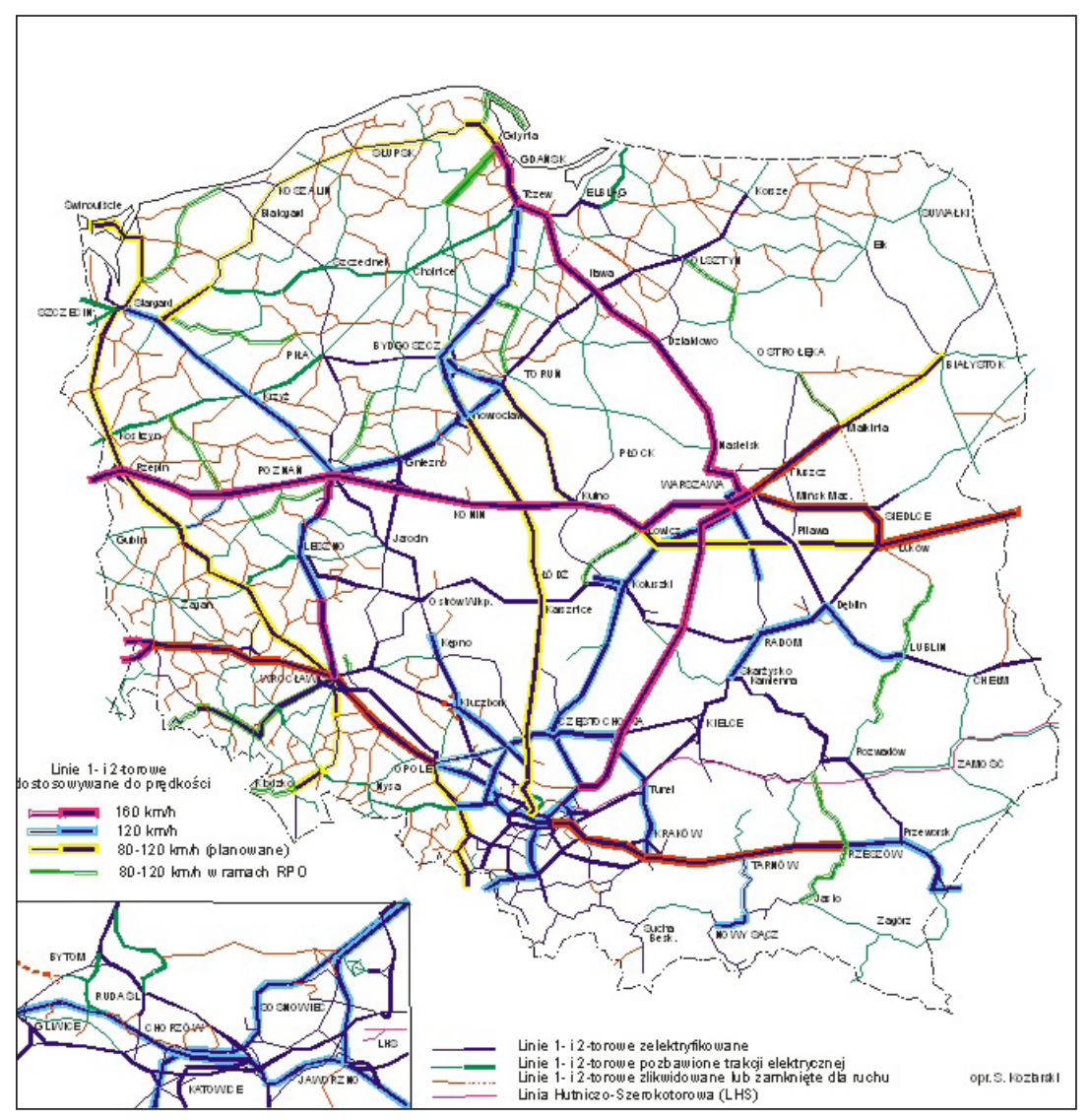

Ryc. 1. Sieć kolejowa Polski (2016).

Źródło: opracowanie własne na podstawie danych PLK.

W ostatnich latach na najważniejszych liniach magistralnych PLK nastąpiło uruchomienie systemu ERTMS/ETCS (poziom 1). System ten przekazano do eksploatacji na następujących odcinkach linii kolejowych w 2009 r.: Legnica - Bielawa Dolna (84 km); w 2010 r.: Warszawa Wschodnia - Nasielsk (56 km), Warszawa Wschodnia - Łowicz (85 km), Grodzisk Mazowiecki - Idzikowice - Zawiercie (CMK, 224 km); w 2011 r.: Łowicz - Poznań Górczyn (227 km), Legnica - Wrocław - Opole Groszowice (152 km); w 2012 r.: Warszawa Zachodnia - Grodzisk Mazowiecki (26 km), Warszawa Wola - Warszawa Praga (9 km), Poznań Górczyn - Zbąszyń - Rzepin (169km), Prabuty Pruszcz Gdański (75 km), Nasielsk - Mława (70 km); w 2013 r.: Wrocław - Rawicz (64 km), Opole Groszowice - Gliwice $(75 \mathrm{~km})$, Rawicz - Poznań (101 km), Warszawa Wschodnia - Tłuszcz (40 km); w 2014 r.: Warszawa Zachodnia - Grodzisk Mazowiecki, Koniecpol - Częstochowa Stradom - Lubliniec - Fosowskie - Opole, Ząbkowice - Jaworzno Szczakowa, Poznań - Czempiń i na trasie Kraków - Tarnów - Rzeszów, zwłaszcza na odcinkach, na których ukończono prace modernizacyjne. W ramach eksploatacji systemu ETCS poziomu 1. na odcinku linii CMK Olszamowice - Zawiercie, umożliwiono prowadzenie ruchu pociągów z prędkością maksymalną 200 km/h.
PKP Polskie Linie Kolejowe są podmiotem odpowiedzialnym za wdrożenie systemu European Rail Traffic Management System ERTMS (Europejski System Zarządzania Ruchem Kolejowym) w Polsce, dlatego spółka sukcesywnie kontynuuje proces realizacji projektów dotyczących implementacji systemu ETCS (Europejski System Sterowania Pociągiem) i GSM-R (Globalny System Kolejowej Radiokomunikacji Ruchomej) współfinansowanych przez Unię Europejską w ramach Programu Operacyjnego Infrastruktura i Środowisko (POliŚ) oraz programu Transeuropejska Sieć Transportowa (TEN-T). Przeprowadzono testy oraz odbiór techniczny urządzeń systemu ETCS poziomu 2. na odcinku Legnica - Węgliniec - Bielawa Dolna. W 2015 r. nastąpiło zakończenie trzech projektów inwestycyjnych związanych z budową sieci GSM-R na liniach kolejowych: E-30 na odcinku Legnica - Wrocław - Opole oraz E-20 Kunowice - Poznań - Łowicz - Warszawa - Terespol. Zrealizowano także budowę systemu GSM-R w ramach modernizacji linii kolejowej Warszawa - Łódź oraz modernizacji linii kolejowej E-65 na odcinku Warszawa - Gdynia. Sieć radiołączności GSM-R na koniec 2015 r. obejmowała 1078 km linii kolejowych, w trakcję prądu stałego 3 kV w 2016 r. wyposażonych było 11874 km linii, a w 2010 r. - 11916 km. Niestety, zmniejsza się 


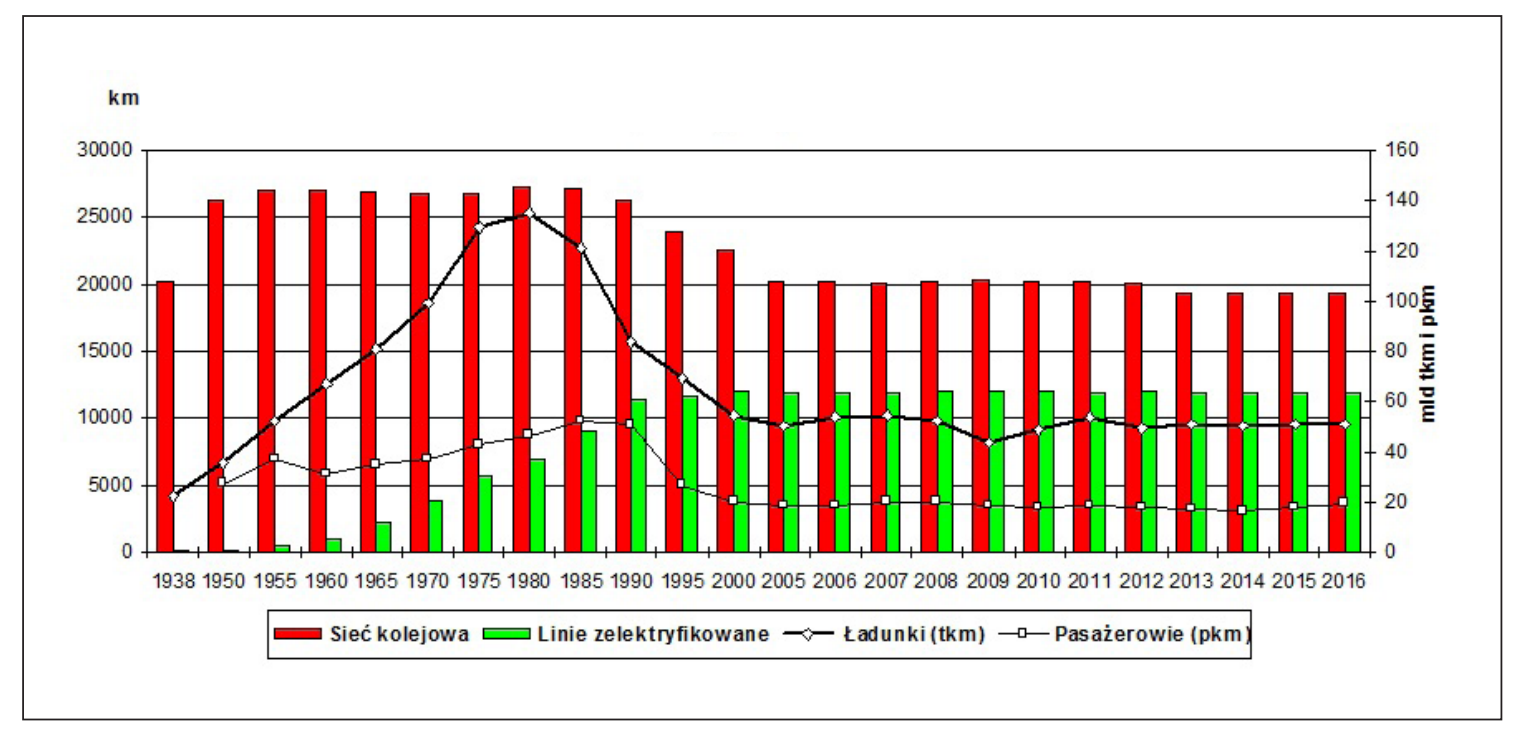

Ryc. 2. Sieć i przewozy kolejowe w Polsce w latach 1938-2016.

Źródło: opracowanie własne na podstawie danych GUS.

długość linii zelektryfikowanych (ryc. 2). Jest to wynikiem zawieszania ruchu lub likwidacji linii, na których drastycznie zmniejszyły się przewozy i nastąpiła konieczność wyłączenia trakcji elektrycznej.

\section{Finansowanie inwestycji kolejowych}

W latach 2005-2016 nakłady inwestycyjne PKP Polskie Linie Kolejowe nieprzerwanie rosły od $0,9 \mathrm{mld}$ zł w 2005 r., poprzez 3,8 mld w 2011 r., do 7,4 mld zł w 2015 r. W 2016 r. - w związku z nową perspektywą finansowania ze środków unijnych - nastąpiło spowolnienie realizacji inwestycji kolejowych, a co za tym idzie obniżeniu uległy również nakłady finansowe do 4,1 mld zł (tab. 2; ryc. 3). W najbliższych latach mają ponownie ulec zwiększeniu wydatki inwestycyjne, czego zapowiedzią są liczba i budżety ogłaszanych przetargów. Świadczy o tym również wartość (ok. 13 mld zł) i liczba zawartych do września 2017 r. nowych umów inwestycyjnych z wykonawcami robót. W spółce PLK oczekiwane jest zdecydowane przyspieszenie realizacji projektów inwestycyjnych.

Wśród najważniejszych inwestycji kolejowych PKP PLK prowadzonych przed 2017 r. wymieniane są prace związane z planowanym na grudzień 2014 r. wprowadzeniem do Polski szybkich pociągów pasażerskich Pendolino. PKP Intercity korzysta z tych składów m.in. na trasach łączących Warszawę z Gdynią, Katowicami, Krakowem i Wrocławiem. Nowy rozkład jazdy pociągów pasażerskich z 2017 r. przyniósł rozszerzenie cieszących się dużym powodzeniem relacji obsługiwanych przez pociągi „Pendolino”. Wydłużono połączenia obsługiwane tego typu pociągami m.in. o relacje Kraków - Rzeszów, Katowice - Bielsko Biała, Wrocław - Jelenia Góra oraz Gdynia - Słupsk - Kosza- lin - Kołobrzeg. Spółka PLK instaluje na tych liniach system ETCS, będący elementem Europejskiego Systemu Zarządzania Ruchem Kolejowym (ERTMS) i umożliwiający prowadzenie pociągów ze zwiększoną do $160 \mathrm{~km} / \mathrm{h}$ prędkością. Modernizacja jest najbardziej zaawansowana na Centralnej Magistrali Kolejowej, łączącej Grodzisk Mazowiecki z Zawierciem, którą kursują szybkie pociągi m.in. z Warszawy do Katowic i Krakowa. Spółka PLK całkowicie przebudowała linię z Warszawy do Gdańska i Gdyni, a na południu kraju przeprowadziła modernizację linii E-30 Zgorzelec - Legnica - Wrocław - Opole oraz Kraków - Tarnów - Rzeszów.

W Wieloletnim Programie Inwestycji Kolejowych (WPIK) według raportów PLK na szlakach pasażerskich nacisk położono na inwestycje torowe $w$ aglomeracjach (np. w Warszawie, Krakowie i na Górnym Śląsku). Drugi kierunek inwestycji w infrastrukturę pasażerską to segment dalekobieżny, obejmujący linie np. z Warszawy do Białegostoku i Lublina oraz z Poznania do Wrocławia i Szczecina, stało się to kosztem połączeń regionalnych. Trzeci kierunek inwestycji objął linie towarowe, które w największym stopniu były zdekapitalizowane. Inwestycje objęły także linie dojazdowe do portów i szlaki wylotowe ze Śląska, np. magistralę węglową łączącą Górny Śląsk z Trójmiastem przez Karsznice, Bydgoszcz oraz magistralę nadodrzańską z Wrocławia do Szczecina przez Zieloną Górę. Skróceniu ma także ulec czas realizacji inwestycji kolejowych, który dotąd był nadmiernie wydłużony, jak to się działo m.in. przy modernizacji linii z Warszawy do Trójmiasta ciągnącej się ponad 10 lat, czy wciąż nieukończonej modernizacji linii Katowice Kraków. 
Tab. 2. Wydatki inwestycyjne PKP PLK w latach 2005-2016 (w mln zł).

\begin{tabular}{|r|r|r|r|r|r|r|r|r|r|r|r|r|}
\hline Lata & 2005 & 2006 & 2007 & 2008 & 2009 & 2010 & 2011 & 2012 & 2013 & 2014 & 2015 & 2016 \\
\hline & 950 & 1376 & 2447 & 3176 & 2814 & 2757 & 3811 & 3921 & 5252 & 7103 & 7415 & 4100 \\
\hline
\end{tabular}

Źródło: Raporty roczne PLK za lata 2006-2015.

Wieloletni Program Inwestycji Kolejowych (WPIK) z lat 2011-2015 - według raportu NIK - nie został dostosowany do możliwości PLK, dlatego zakres ujętych w nim zadań inwestycyjnych okazał się niemożliwy do wykonania w zaplanowanych terminach. Do końca 2015 r. nie zakończono niemal połowy ze 153 projektów ujętych w programie i nie wykorzystano ponad 11,3 mld zł zaplanowanych w 2011 r. ze środków unijnych na infrastrukturę kolejową. Te pieniądze pozwoliłyby na zmodernizowanie ok. 1650 $\mathrm{km}$ linii kolejowych wraz z infrastrukturą towarzyszącą.

W ramach realizacji WPIK w latach 2011-2015 za 22,7 mld zł zmodernizowano $3318 \mathrm{~km}$ linii kolejowych wraz z infrastrukturą towarzyszącą (obiekty inżynierskie, skrzyżowania, krawędzie peronowe, zwiększenie maksymalnej prędkości jazdy i dopuszczalnego nacisku osi). Modernizacja $1 \mathrm{~km}$ linii kolejowej kosztowała średnio ok. 6,85 mln zł. Do końca 2015 r. w ramach Wieloletniego Programu Inwestycji Kolejowych nie zrealizowano zaplanowanych modernizacji: 490 km linii kolejowych, 625 km torów szlakowych i głównych, $586 \mathrm{~km}$ pozostałych torów, 635 obiektów inżynieryjnych, 74 skrzyżowań z drogami, 185 krawędzi peronowych. Ponadto na długości $649 \mathrm{~km}$ nie uzyskano możliwości osiągania maksymalnej prędkości $160 \mathrm{~km} / \mathrm{h}$, a na długości $330 \mathrm{~km}$ nie uzyskano zakładanej prędkości $200 \mathrm{~km} / \mathrm{h}$.

Do końca 2015 r. nie wykorzystano części zaplanowanych środków POliś (blisko $6 \mathrm{mld}$ zł), z czego ok. 2,4 mld zł zostało wykorzystane na zwiększenie unijnego dofinansowania inwestycji miejskich, a kwota 3,5 mld zł została utracona. Konsekwencją braku realizacji inwestycji do końca 2015 r. była konieczność wystąpienia do Komisji Europejskiej o zgodę na ujęcie kontynuowania finansowania inwestycji ze środków perspektywy 2014-2020. Do kwietnia 2016 r. uzyskano takie decyzje w odniesieniu do 9 projektów (fazowanie inwestycji).

W listopadzie 2016 r. rząd RP zatwierdził Krajowy Program Kolejowy do 2023 r. Dotychczas inwestycje kolejowe nie układały się w spójną całość. PLK budowały najczęściej tam, gdzie był komplet dokumentacji projektowej i pozwoleń. Założenie jest takie, że w 2023 r. po koncentracji inwestycji na wybranych precyzyjnie szlakach ma być gotowa spójna, zmodernizowana sieć kolejowa.

Cel główny Krajowego Programu Kolejowego (KPK) obejmuje wzmocnienie roli transportu kolejowego w zintegrowanym systemie transportowym kraju

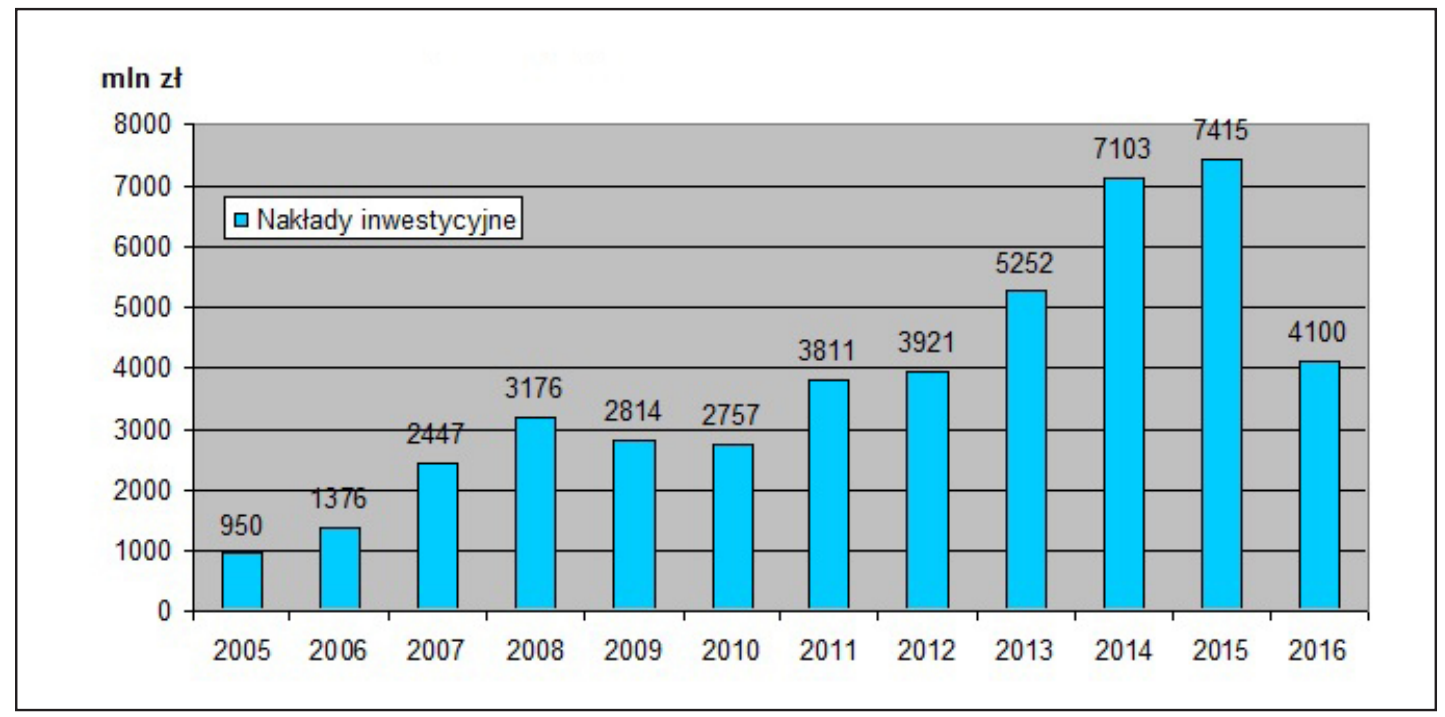

Ryc. 3. Nakłady inwestycyjne PLK w latach 2005-2016 (w mln zł). 
poprzez stworzenie spójnej i nowoczesnej sieci linii kolejowych. Komplementarne wobec celu głównego są cele szczegółowe, które obejmują: 1. wzmocnienie efektywności transportu kolejowego, 2. zwiększenie bezpieczeństwa funkcjonowania transportu kolejowego, 3. poprawę jakości w przewozach pasażerskich i towarowych. Cele szczegółowe Krajowego Programu Kolejowego obejmują: Cel 1 - Wzmocnienie efektywności transportu kolejowego to:

- poprawa stanu technicznego bazowej i kompleksowej sieci TEN-T, w tym kontynuacja prac w korytarzach CE-30, E-20/CE-20, E-59/CE-59, E-65/CE$65, \mathrm{E}-75$, a także w korytarzach stanowiących połączenia międzynarodowe,

- poprawa przepustowości linii w obrębie aglomeracji, dojazdów do nich oraz na odcinkach, na których zidentyfikowano niewystarczającą zdolność przepustową,

- uzyskanie atrakcyjnego czasu przejazdu pociągów względem ruchu drogowego,

- realizacja projektów istotnych dla poszczególnych regionalnych systemów transportowych,

- inwestycje w ciągu "Magistrali Wschodniej” (linia 51): Rzeszów / Kielce - Lublin - Białystok - Olsztyn;

- wzakresie poprawy stanu infrastruktury stanowiącej dostęp do portu w Szczecinie.

Cel 2 - Zwiększenie bezpieczeństwa funkcjonowania transportu kolejowego to:

- wdrażanie ERTMS/ETCS i ERTMS/GSM-R,

- poprawa jakości oferty i bezpieczeństwa infrastruktury udostępnianej przewoźnikom.

Cel 3 - Poprawa jakości w przewozach pasażerskich i towarowych to:

- poprawa stanu technicznego linii kolejowych tworzących tzw. korytarze towarowe europejskiej sieci kolejowej ukierunkowanej na konkurencyjny transport towarowy;

- poprawa stanu infrastruktury obsługującej kolejowe przejścia graniczne na styku linii normalnoi szerokotorowych (1435 i $1520 \mathrm{~mm}$ ),

- poprawa połączeń Warszawy z rejonami ważnymi dla obszarów o najniższej dostępności transportowej, poprawa połączeń między miastami wojewódzkimi, a także między innymi ważnymi ośrodkami gospodarczymi, zapewnienie sprawnych połączeń kolejowych z portami morskimi w celu integracji różnych gałęzi transportu,

- poprawa stanu technicznego linii szczególnie ważnych dla ruchu towarowego, w tym:

- zapewniających ominięcie aglomeracji warszawskiej, poznańskiej i górnośląskiej (Katowic),

- poprawiających dostęp do portów morskich w Gdańsku, Gdyni, Szczecinie i Świnoujściu,

- stanowiących wyprowadzenia z innych punktów tworzących największe potoki przewozowe.
Tab. 3. Wydatki inwestycyjne PKP PLK w latach 2005-2016 (w mln zł).

\begin{tabular}{|l|c|}
\hline \multicolumn{1}{|c|}{ Projekty } & Kwoty w mln zł \\
\hline Fundusz Spójności & 49559,7 \\
\hline CEF & 18419,0 \\
\hline POliŚ 2014-2020 & 28166,8 \\
\hline POliś 2007-2013 & 2973,9 \\
\hline PO PW & 2094,3 \\
\hline RPO & 4743,5 \\
\hline RPO 2014-2020 & 4667,0 \\
\hline RPO 2007-2013 & 76,5 \\
\hline Środki krajowe & 9997,9 \\
\hline Program obronny & 54,3 \\
\hline Ogółem & 66449,7 \\
\hline
\end{tabular}

Źródło: Krajowy Program Kolejowy do 2023 r., Infrastruktura kolejowa zarządzana przez PKP PLK, listopad 2016 r.

Transeuropejska Sieć Transportowa (TEN-T) oparta jest na rozporządzeniu Parlamentu Europejskiego i Rady UE z 11 grudnia 2013 r. Program polega na stworzeniu w Europie sieci składającej się z dróg, punktowych elementów sieci oraz inteligentnych systemów transportowych. W części kolejowej polega na wytyczeniu 9 paneuropejskich korytarzy, czyli obszarów o znaczeniu strategicznym dla przewozów pasażerskich i towarowych. Do 2030 r. ma powstać sieć bazowa, a uzupełni ją sieć komplementarna, planowana do $2050 \mathrm{r}$.

Przez Polskę będą przebiegały 2 korytarze sieci bazowej: korytarz z północy na południe Bałtyk - Adriatyk oraz ze wschodu na zachód Bałtyk - Morze Północne. Sieć bazowa wymaga pełnej elektryfikacji linii, w miarę możliwości też bocznic, aby uzyskać warunki do prowadzenia pociągów o długości $740 \mathrm{~m}$, jeżdżących z prędkością $100 \mathrm{~km} / \mathrm{h}$. Na tych liniach ma być wykorzystywany system zarządzania ruchem ERMTS.

W celu sfinansowania rozwoju sieci TEN-T stworzono fundusz Connecting Europe Facility (CEF). Na realizację tego projektu przewidziano $26 \mathrm{mld} €$ na inwestycje o charakterze ogólnoeuropejskim (w tym $11 \mathrm{mld} €$ na infrastrukturę zostało przeniesione z Funduszu Spójności). Co roku mają się odbywać dwa konkursy: jeden skierowany tylko do krajów będących beneficjentami Funduszu Spójności (tam dofinansowanie może sięgać do 85\%), drugi dla wszystkich (dofinansowanie do 50\%). Pierwsze konkursy zostały ogłoszone jesienią 2014 r. Od ogłoszenia konkursu do przekazania środków mija ok. 9-10 miesięcy. Do 2016 r. państwa nie będą rywalizować, gdyż środ- 
ki mają być rozdzielane w tzw. kopertach krajowych. Dla naszego kraju przeznaczono 4,4 mld €, z czego na transport kolejowy $-3,4$ mld $€$.

W nowej perspektywie finansowej na lata 2014 2023 dla transportu kolejowego w KPK przewidziano kwotę 66,4 mld zł. Polskie Linie Kolejowe dla perspektywy finansowej 2014-2020 opracowały Krajowy Program Kolejowy (dokument programowy), w którym ujęto projekty inwestycyjne m.in. z funduszu spójności o łącznej wartości 49,5 mld zł, funduszu CEF - 18,4 mld zł, POilś - 28,1 mld zł, programu operacyjnego Polski Wschodniej - 2,0 mld zł, Regionalnych Programów Operacyjnych - 4,6 mld zł i z pozostałych programów krajowych - 9,9 mld zł. Dodatkowo zarządca infrastruktury ubiegał się o środki z nowego mechanizmu finansowego UE - Funduszu "Łącząc Europę". W 2014 r., w pierwszym naborze w ramach wspomnianego funduszu CEF, Polska zgłosiła 7 projektów kolejowych o wartości ok. 1,922 mld €, do drugiego naboru 9 projektów o wartości 2,0 mld €, a do trzeciego 5 projektów o wartości 1,9 mld €. Projekty CEF dla sieci kolejowej Polski zestawiono w tabeli zbiorczej KPK (tab. 3).

W latach 2011-2015 spółka PLK zawarła z Europejskim Bankiem Inwestycyjnym 12 umów kredytowych z przeznaczeniem na finansowanie następujących projektów kolejowych:

- $120 \mathrm{mln} €$ dla modernizacji linii kolejowej E-59 na odcinku Wrocław - granica woj. dolnośląskiego (POliś);

- $308 \mathrm{mln} €$ dla modernizacji linii kolejowej E-30/ CE-30, odcinek Kraków - Rzeszów, etap III; POliŚ;

- $100 \mathrm{mln} €$ dla modernizacji linii kolejowej Warszawa - Łódź Lot A i C (POliś);

- 65 mln euro dla modernizacji linii kolejowej E-59, odcinek Czempiń - Poznań, etap II (POliŚ);

- 40 mln $€$ dla modernizacji linii kolejowej E-20, etap II, odcinek Siedlce - Terespol (POliś);

- $235 \mathrm{mln}$ euro dla modernizacji linii kolejowej $\mathrm{nr} 8$ Warszawa - Radom, Lot A, B, F i C, D, E;

- $268 \mathrm{mln} €$ dla modernizacji linii kolejowej E-30, etap II, odcinek Zabrze - Katowice -Kraków;

- 180 mln $€$ dla modernizacji linii kolejowej E-75 Rail Baltica Warszawa - Białystok - granica z Litwą, odcinek Warszawa Rembertów - Zielonka Tłuszcz (Sadowne);

- $100 \mathrm{mln}$ euro dla projektów rewitalizacyjnych (9 projektów przejazdowych oraz 2 projekty liniowe);

- 100 mln $€$ dla modernizacji linii kolejowej E-59 na odcinku Wrocław - Poznań, etap IV, odcinek granica województwa dolnośląskiego - Czempiń;

- 200 mln euro dla modernizacji linii kolejowej E-20 na odcinku Warszawa - Poznań - pozostałe roboty, odcinek Sochaczew - Swarzędz;
- 60 mln $€$ dla modernizacji warszawskiego węzła kolejowego (linii obwodowej w Warszawie (odc. Warszawa Gołąbki/Warszawa Zachodnia - Warszawa Gdańska oraz linii kolejowej Warszawa Włochy - Grodzisk Mazowiecki (linia nr 447).

\section{Inwestycje modernizacyjne PLK}

Przygotowanie infrastruktury technicznej linii do parametrów eksploatacyjnych określonych w umowach AGC i AGTC obejmuje modernizację szlaku do szybkości $160 \mathrm{~km} / \mathrm{h}$, pociągów zestawionych z taboru klasycznego w ruchu pasażerskim, natomiast w ruchu towarowym - do prędkości $120 \mathrm{~km} / \mathrm{h}$ oraz przystosowanie nawierzchni do nacisku osiowego $221 \mathrm{kN}$. W ramach inwestycji wykonuje się pełną modernizację linii, a przede wszystkim: 1. przebudowę układów torowych wraz z korektą łuków i wymianą rozjazdów oraz odwodnieniem nasypów i wykopów; 2. wymianę podtorza i nawierzchni wraz ze wzmocnieniem słabych miejsc; 3. modernizację i wymianę sieci trakcyjnej 3 kV wraz z układem zasilania; 4. modernizację sieci i urządzeń elektroenergetyki nietrakcyjnej; 5 modernizację i wymianę systemów sterowania ruchem kolejowym i diagnostyki; 6 . likwidację przejazdów i przejść dla pieszych w poziomie szyn poprzez budowę dwupoziomowych skrzyżowań bezkolizyjnych z drogami (wiadukty, kładki dla pieszych i przejścia podziemne); 7. zwiększenie nośności istniejących i budowa nowych obiektów inżynieryjnych, takich jak: mosty, wiadukty i przepusty; 8. przebudowę budynków stacyjnych wraz z peronami oraz dostosowanie ich do norm i standardów UE; 9. z zakresu ochrony środowiska - poprawa klimatu akustycznego poprzez np. budowę ekranów akustycznych, specjalnych konstrukcji podtorza wyposażonych w maty antywibracyjne itp.; 10. minimalizację negatywnego oddziaływania inwestycji na środowisko poprzez budowę oczyszczalni wód opadowych, uszczelnienie obiektów inżynieryjnych itp.; 11. uzyskanie poprawy oferty przewozowej, a w konsekwencji zwiększenie liczby klientów poprzez: zwiększenie komfortu podróży, skrócenie czasu przejazdu, zwiększenie konkurencyjności kolei w wyniku wzrostu prędkości i poprawy punktualności pociągów, zwiększenie bezpieczeństwa podróżnych, dostosowanie infrastruktury kolejowej do potrzeb osób o ograniczonych możliwościach ruchowych (Koziarski, 2014).

Poza wspomnianą powyżej całkowitą modernizacją linii kolejowych do parametrów europejskich z procesem inwestycyjnym wiąże się również pojęcie rewitalizacji. Rewitalizacja linii kolejowych ma prowadzić m.in. do: 1. utrzymania obecnych nacisków na oś wynoszących 211-221 kN; 2. przywrócenia prędkości projektowej pociągów pasażerskich i towarowych na 
danym odcinku; 3. spełnienia wymagań dotyczących technicznej specyfikacji interoperacyjności dla poszczególnych podsystemów; 4 zwiększenia efektywności systemu sterowania ruchem; 5 . zwiększenia bezpieczeństwa na jednopoziomowych przejazdach kolejowych, m.in. poprzez wyposażenie przejazdów w samoczynną sygnalizację przejazdową; 6 . poprawy jakości przewozów i wzrost efektywności po zakończeniu rewitalizacji celem osiągnięcia wyższej prędkości handlowej, skrócenia czasu jazdy i zwiększenia przepustowości linii; 7. zachowania dotychczasowych funkcji wybranych stacji z możliwością osiągnięcia lepszej ilościowo oferty przewozowej; 8. ograniczenia uciążliwości dla środowiska naturalnego w zakresie np. hałasu; 9. zmniejszenia kosztów bieżącego utrzymania infrastruktury z tytułu wymiany wyeksploatowanych i zastosowania nowych elementów; 10. uzyskania poprawy oferty przewozowej, a w konsekwencji zwiększenia ilości klientów przez: zwiększenie komfortu podróży, skrócenie czasu podróży, zwiększenie konkurencyjności kolei (prędkośći i punktualność), wzrost bezpieczeństwa ruchu.

W ogólnym zarysie modernizacja polega na rozbiórce linii kolejowej i budowie jej prawie od podstaw z wykorzystaniem dotychczas zajmowanego terenu. Kompleksowej wymianie podlegają wówczas tory. W miejsce przestarzałych, wyeksploatowanych urządzeń powstaje nowoczesny system sterowania ruchem kolejowym. Modernizowane są wszystkie mosty, wiadukty i przepusty. Rozmiar prac można porównać do budowy nowej linii kolejowej: prace prowadzi się najczęściej z utrzymaniem ruchu. Takie rozwiązania wymagają też szczególnych zasad bezpieczeństwa i dobrej organizacji pracy, gdyż obok przejeżdżających pociągów pracują ludzie i maszyny budowlane. Efektem prac jest wyższa prędkość pociągów pasażerskich (do $160 \mathrm{~km} / \mathrm{h}$ ), dzięki czemu ulega skróceniu czas przejazdu. Modernizacja obejmuje również infrastrukturę obsługi podróżnych na stacjach i przystankach. Obiekty są wyposażone w wiaty, czytelny system informacji oraz dostosowane do potrzeb osób o ograniczonej sprawności ruchowej.

Polepszenie jakości usług przewozowych dzięki poprawie stanu technicznego linii kolejowych $w$ ramach rewitalizacji ma się uzyskać poprzez: 1. wymianę nawierzchni torów z oczyszczeniem i uzupełnieniem podsypki tłuczniowej; 2 . profilowanie ław torowiska; 3. zastosowanie warstwy ochronno-filtracyjnej na podtorzu; 4 . wymianę rozjazdów z wymianą podsypki tłuczniowej oraz zastosowaniem warstwy filtracyjnej; 5. odtworzenie odwodnienia; 6. modernizację urządzeń zabezpieczenia ruchu kolejowego poprzez wymianę m.in. napędów zwrotnicowych, urządzeń przytorowych, elektrycznego ogrzewania rozjazdów itp.; 7. modernizację systemów energetyki, m.in. poprzez naprawę, regulację lub demontaż i wymianę sieci trakcyjnej.

Poprawa stanu technicznego sieci kolejowej ma na celu stworzenie odpowiedniego poziomu usług transportowych i wprowadzenie europejskich standardów do procesu przewozowego. W ostatnich latach prowadzono prace modernizacyjne na liniach wchodzących w skład transeuropejskiej sieci transportowej. Inwestycje kolejowe realizowano ze środków budżetu państwa, Funduszów: Spójności, Kolejowego, TEN-T oraz środków własnych PLK.

W latach 2001-2010 z funduszu ISPA prowadzono modernizację m.in. linii kolejowych: E-20 Siedlce - Terespol oraz węzła poznańskiego, E-30 Węgliniec Legnica $(37,2 \mathrm{~km})$, Węgliniec - Zgorzelec $(26,5 \mathrm{~km})$ i Węgliniec - Bielawa Dolna (12,5 km) oraz linii E-65 Warszawa-Gdynia na odcinkach: Warszawa Wschodnia - Świercze (z budową 16 skrzyżowań dwupoziomowych), Szymankowo - Pruszcz Gdański (z budową 6 skrzyżowań dwupoziomowych) oraz modernizację stacji Gdynia Główna Osobowa.

W latach 2008-2013 z Programu Operacyjnego Infrastruktura i Środowisko prowadzono modernizację następujących linii kolejowych: E-65 Warszawa Gdynia (obszary Lokalnego Centrum Sterowania: Działdowo, Ciechanów, lława, Malbork, Gdańsk, Gdynia), E-30 Kraków - Rzeszów (138,7 km), Sosnowiec Jęzor - Jaworzno Szczakowa (58,2 km), E-59 Wrocław - Żmigród i Czempiń - Poznań (32,3km), Warszawa - Skierniewice $(57,4$ km) i Skierniewice - Łódź Widzew oraz E-75 Rail Baltica Warszawa Rembertów - Zielonka - Tłuszcz (66,5 km) (ryc. 4).

W 2012 r. rozpoczęto prace związane z modernizacją pierwszej części trasy wiodącej do krajów bałtyckich, tj. linii Rail Baltica. Zrealizowany etap polegał na przebudowie odcinka Warszawa - Tłuszcz i wiązał się m.in. z oddzieleniem ruchu podmiejskiego i dalekobieżnego. Inną kluczową inwestycją była budowa otwartej dla ruchu z końcem 2016 r. nowej stacji Łódź Fabryczna - nowoczesnej podziemnej budowli, która może w przyszłości - po realizacji zatwierdzonego do budowy tunelu w kierunku Łodzi Kaliskiej - obsługiwać szybkie pociągi pasażerskie KDP na trasie Warszawa - Łódź - Wrocław / Poznań (projektowana linia wielkich prędkości tzw. "Y") (ryc. 5; tab. 4).

PLK, przy współudziale środków Unii Europejskiej, realizuje zadania inwestycyjne, które przyczynią się do poprawy stanu technicznego infrastruktury. $\mathrm{Ce}-$ lem działalności inwestycyjnej jest osiągnięcie integracji polskiego transportu kolejowego z systemem Unii Europejskiej w aspekcie wymaganych standardów technicznych, jak i interoperacyjności linii kolejowych. 


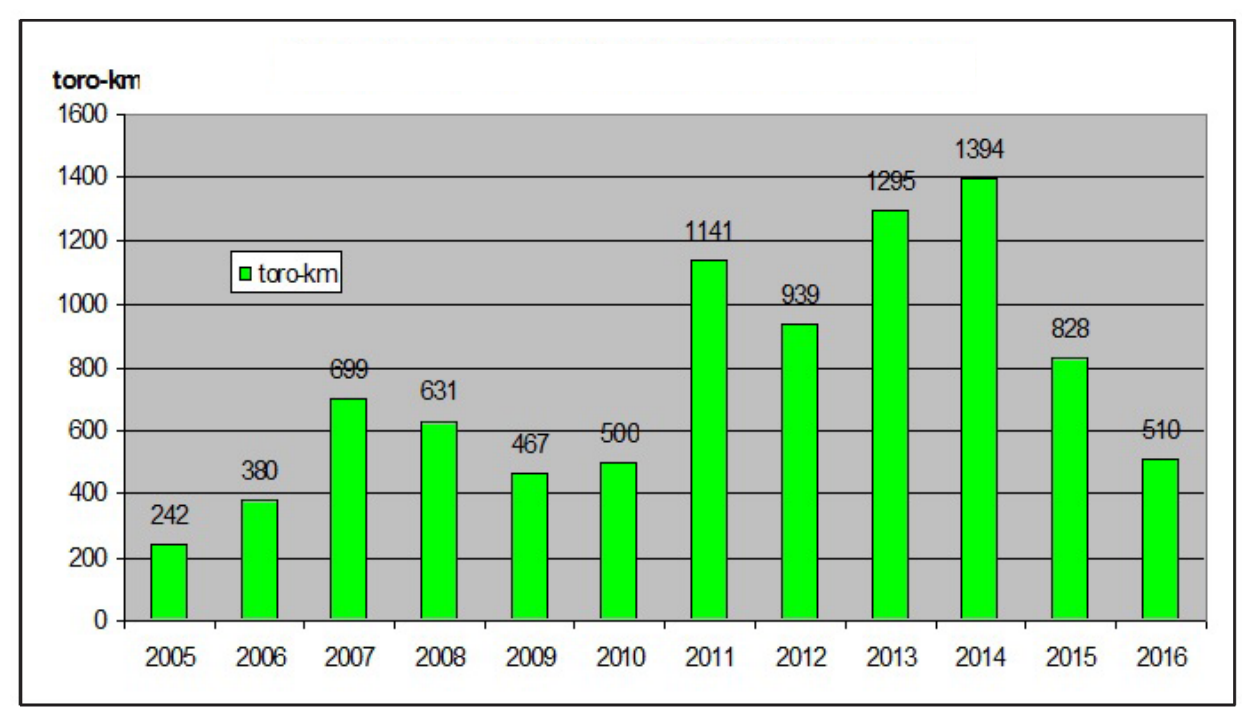

Ryc. 4. Modernizacja torów PLK w latach 2005-2016 w toro-km.

Źródło: opracowanie własne na podstawie danych PLK.

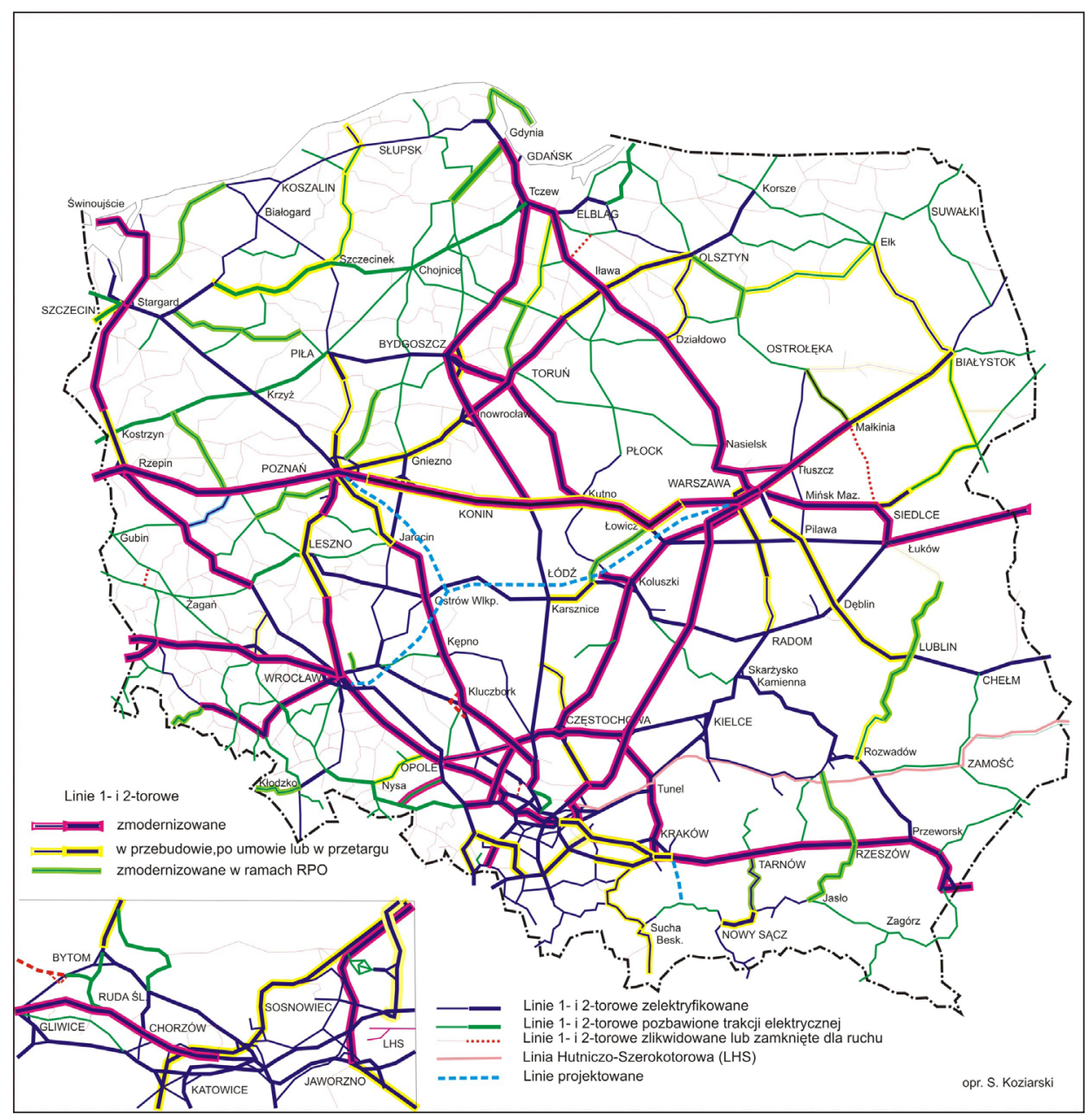

Ryc. 5. Modernizacja sieci kolejowej Polski do 2017 r.

Źródło: opracowanie własne na podstawie danych PLK. 
W latach 2010-2013 ze środków finansowych budżetu państwa, funduszu kolejowego lub środków własnych PLK prowadzono modernizację m.in. linii: Grodzisk Mazowiecki - Opoczno - Włoszczowa Północ - Zawiercie (CMK), Psary - Kozłów, SkarżyskoKamienna - Ocice, Gliwice Łabędy - Pyskowice - Błotnica Strzelecka, Przemyśl - Medyka, Zgierz - Kutno, Szczecin - Świnoujście, Poznań - Rokitnica. Do 2016 r. kontynuowana była rewitalizacja całych bądź fragmentów linii: Gliwice Łabędy - Katowice - Sosnowiec Jęzor, Bydgoszcz Główna - Tczew, Wrocław - Jelenia Góra, Radom - Kielce, Głogów - Zielona Góra - Rzepin - Dolna Odra oraz Inowrocław - Zduńska Wola - Chorzów Batory.
Lublin - Lubartów - Parczew, Lublin - Kraśnik, Krasnystaw - Zawada (Zamość), Dorohusk - Wólka Okopska; w lubuskim: Krzyż - Kostrzyn, Zbąszynek - Sulechów - Czerwieńsk wraz budową łącznicy Pomorsko - Przylep (2,1 km), Zbąszynek - Międzyrzecz - Skwierzyna - Gorzów Wielkopolski; w łódzkim: Bednary Zgierz, Łódź Widzew - Zgierz; w małopolskim: Tarnów - Stróże, Kraków Bonarka - Kraków Swoszowice; w podkarpackim: Rzeszów - Jasło, Jasło - Krosno Sanok i Rzeszów - Kolbuszowa - Nowa Dęba - Tarnobrzeg; w pomorskim: Kościerzyna - Gdynia, Reda - Władysławowo - Hel; w wielkopolskim: Wolsztyn - Grodzisk Wielkopolski - Luboń koło Poznania, Poznań Wschód - Wągrowiec; w warmińsko-mazur-

Tab. 4. Realizacja inwestycji kolejowych w latach 2012-2015-2016.

\begin{tabular}{|c|c|c|c|c|}
\hline Wyszczególnienie & Jednostka & 2012 & 2015 & 2016 \\
\hline Modernizacja torów & $\mathrm{km}$ & 940 & 828 & 510 \\
\hline Zabudowa rozjazdów & szt. & 239 & 1271 & 549 \\
\hline Obiekty inżynieryjne & szt. & . & 500 & . \\
\hline Mosty & szt. & 61 & 87 & . \\
\hline Wiadukty & szt. & 77 & 118 & 65 \\
\hline Przepusty & szt. & 316 & 295 & . \\
\hline Perony & szt. & 113 & 144 & 109 \\
\hline Sieć trakcyjna & toro-km & . & 607 & . \\
\hline Ekrany akustyczne & $\mathrm{km}$ & . & 89 & . \\
\hline Przejazdy kolejowe & szt. & . & 681 & 213 \\
\hline
\end{tabular}

Uwaga: - - brak danych

Źródło: Raporty roczne PLK za 2012 i 2015 r.

Inwestycje te są również prowadzone w ramach Programu Operacyjnego Infrastruktura i Środowisko. W latach 2012-2016 realizowana była rewitalizacja stanu technicznego linii: Toruń - Bydgoszcz, Kalety - Lubliniec - Kluczbork - Ostrzeszów, Zawiercie - Dąbrowa Górnicza Ząbkowice - Jaworzno Szczakowa, Inowrocław - Toruń - Jabłonowo Pomorskie, Koluszki - Częstochowa, Koniecpol - Częstochowa - Lubliniec - Fosowskie - Opole i Błotnica Strzelecka - Opole Groszowice.

W latach 2007-2012 PKP Polskie Linie Kolejowe realizowały projekty modernizacji linii kolejowych współfinansowane z Europejskiego Funduszu Rozwoju Regionalnego w ramach Regionalnych Programów Operacyjnych, które przykładowo w województwie dolnośląskim objęły linie: Jelenia Góra Szklarska Poręba Górna, Duszniki Zdrój - Kudowa Zdrój; w kujawsko-pomorskim: Torun - Bydgoszcz, Toruń - Chełmża - Grudziądz; w lubelskim: Lublin Świdnik - terminal Portu Lotniczego Lublin $(2,2 \mathrm{~km})$, skim: Olsztyn - Szczytno - Szymany, Szczytno - Wielbark oraz w zachodnio-pomorskim: Goleniów - Nowogard - Gryfice - Trzebiatów - Kołobrzeg i Ulikowo (Stargard Szczeciński) - Kalisz Pomorski - Wałcz.

W latach 2011-2015 na realizację WPIK zostały poniesione wydatki w łącznej wysokości ok. 22 732,95 mln zł. Tylko w 2015 r. PKP PLK realizowała działania inwestycyjne na 101 projektach, w tym na 26 projektach przygotowawczych i 75 projektach obejmujących roboty budowlane (w tym ERTMS - 39), z czego zakończonych zostało 47 projektów. W wyniku realizacji projektów WPIK w latach 2011-2015 w ramach działań modernizacyjnych, rewitalizacyjnych oraz przebudowy i budowy poprawiony został stan infrastruktury kolejowej na: ok. 3318 km linii kolejowych, 5375 km linii zasadniczych, ok. 3042 obiektach inżynieryjnych oraz 2635 skrzyżowaniach linii kolejowych z drogami (tab. 5). W wyniku prac modernizacyjnych uzyskano łącznie $923 \mathrm{~km}$ (59\% planu) torów szlakowych dostosowanych do prędkości $160 \mathrm{~km} / \mathrm{h}$ i $180 \mathrm{~km}$ 
Tab. 5. Realizacja inwestycji kolejowych w latach 2011-2015.

\begin{tabular}{|c|c|c|c|c|}
\hline Miernik & Plan & $\begin{array}{l}\text { Wyko- } \\
\text { nanie }\end{array}$ & $\begin{array}{c}\text { Wyko- } \\
\text { nanie/ } \\
\text { Plan } \\
\%\end{array}$ & $\begin{array}{l}\text { Nie zreali- } \\
\text { zowano }\end{array}$ \\
\hline Długość linii kolejowych [km] & 3808 & 3318 & 87,1 & -490 \\
\hline Długość torów głównych zasadniczych i szlakowych [km] & 6000 & 5375 & 89,6 & -625 \\
\hline Długość wszystkich torów [km] & 6368 & 5782 & 90,8 & \\
\hline Liczba obiektów inżynierskich [szt.] & 3677 & 3042 & 82,7 & -635 \\
\hline Liczba skrzyżowań [szt.] & 2709 & 2635 & 97,3 & \\
\hline Liczba krawędzi peronowych [szt.] & 1151 & 966 & 83,9 & \\
\hline Długość torów szlakowych z maksymalną prędkością 160 km/h [km] & 1572 & 923 & 58,7 & -649 \\
\hline Długość torów szlakowych z maksymalną prędkością 200 km/h [km] & 510 & 180 & 35,3 & -330 \\
\hline Długość torów szlakowych z dopuszczalnym naciskiem osi 221 kN [km] & 4069 & 3834 & 94,2 & -235 \\
\hline
\end{tabular}

Źródło: Realizacja Wieloletniego Programu Inwestycji Kolejowych, Informacja o wynikach kontroli Departament Infrastruktury NIK, Raport NIK, 16.12.2016 r.

(35\% planu) wspomnianych torów dostosowanych do maksymalnej prędkości 200 km/h. Niektóre z inwestycji modernizacyjnych PLK objęły linie ważne w krajowym systemie przewozów pasażerskich. Impulsem do podjęcia tych prac modernizacyjnych były również przygotowania kolei do wykonywania przewozów pasażerskich w ramach Mistrzostw Europy w Piłce Nożnej Euro 2012 rozgrywanych także w Polsce. W tym celu prowadzono fragmentaryczną modernizację linii kolejowych na odcinkach Poznań - Gniezno - Inowrocław - Bydgoszcz - Gdańsk.

PKP Polskie Linie Kolejowe opracowały listę inwestycji, których realizacja przewidziana jest w perspektywie budżetowej Unii Europejskiej na lata 2014-2020. Niektóre z nich są na zaawansowanym etapie przygotowania, planowane jest ogłoszenie postępowań na studia wykonalności. Jedną z głównych inicjatyw jest podniesienie efektywności projektów inwestycyjnych w przyszłej perspektywie.

Przygotowania do modernizacji linii kolejowych w latach 2014-2023 pochłonęły prawie 40,6 mln zł. Na prace te PLK otrzymały dofinansowanie ze środków unijnych w wysokości $28 \mathrm{mln}$ zł. Prace przygotowawcze objęły odcinki: Kutno - Toruń Główny, Ełk Korsze wraz z elektryfikacją, Skarżysko-Kamienna - Kielce - Kozłów, Kluczbork - Oleśnica - Wrocław Mikołajów, Łódź Kaliska - Zduńska Wola - Ostrów Wielkopolski, Wyczerpy - Chorzew Siemkowice, Częstochowa - Zawiercie, Kraków Płaszów - Skawina Oświęcim, Skawina - Sucha Beskidzka - Chabówka - Zakopane (wraz z budową łącznicy w Suchej Beskidzkiej), Toszek Północ - Rudziniec Gliwicki - Stare Koźle, Legnica - Rudna Gwizdanów, Opole Groszowi- ce - Jelcz - Wrocław Brochów ${ }^{3}$. Oddzielnie - w ramach zadania POliś - przygotowana zostanie dokumentacja przedprojektowa dla prac na linii kolejowej nr 202 na odcinku Gdynia Chylonia - Słupsk. W perspektywie inwestycyjnej do 2023 r. kompleksowo zostanie również rozwiązany problem stanu technicznego infrastruktury kolejowej związany z dostępem do portów morskich. Analizy niezbędne do wykonania tych prac obejmują linie prowadzące do portów w Gdańsku, Gdyni, Szczecinie i Świnoujściu.

\section{Rewitalizacja linii kolejowych}

Program rewitalizacji linii kolejowych realizowany w latach 2011-2016 przez PKP Polskie Linie Kolejowe, przy wsparciu środków unijnych z Programu Operacyjnego Infrastruktura i Środowisko, miał wartość ok. 3,6 mld zł. Obejmował on 12 inwestycji polegających na odtworzeniu parametrów technicznych wyeksploatowanych linii kolejowych, czyli przywróceniu prędkości przejazdowych do $120 \mathrm{~km} / \mathrm{h}$, a także na odnowieniu peronów, co bezpośrednio przekłada się na komfort podróżujących koleją. Program rewitalizacji na sieci kolejowej zarządzanej przez PLK zakładał remont łącznie 560 km linii kolejowych (tj. ok. 870 km torów), a także odnowienie 126 peronów i 365 obiektów inżynieryjnych oraz modernizację - w celu po-

Zauważmy znaczną zgodność zestawienia z listą uruchomionych w 2017 r. przetargów i zawartych umów na przebudowę linii kolejowych przedstawioną w dalszej części opracowania. 
prawy bezpieczeństwa ruchu - przejazdów kolejowo-drogowych.

Rewitalizacja, czyli przywrócenie parametrów technicznych linii kolejowej po długim okresie eksploatacji, była najszybszą i najtańszą metodą usprawnienia ruchu kolejowego. Pozwala na likwidację ograniczeń prędkości oraz zwiększenie bezpieczeństwa ruchu. Prace rewitalizacyjne nie wymagają uzyskania wielu pozwoleń administracyjnych niezbędnych do rozpoczęcia robót, gdyż nie zmieniają istotnie warunków lokalizacyjnych oraz środowiskowych. Pozwalało to znacznie skrócić proces przygotowawczy inwestycji w porównaniu z modernizacją.

Do wspomnianego programu rewitalizacji doszedł jeszcze dwuetapowy projekt przejazdowy, który zakładał podniesienie poziomu bezpieczeństwa na ponad 300 przejazdach kolejowych w całym kraju, a także projekt rozjazdowy obejmujący modernizację niemal 700 rozjazdów znajdujących się na 31 liniach kolejowych i 142 posterunkach ruchu. Realizacja tych zadań zwiększyła bezpieczeństwo przejazdu pociągów na rozjazdach i przejazdach kolejowych, a w miejscach ich modernizacji zlikwidowane zostały ograniczenia prędkości, co zdecydowanie poprawi komfort jazdy i skróci czas podróży koleją.

W ramach programu rewitalizacyjnego PKP Polskie Linie Kolejowe zrealizowały prace na następujących trasach: Toruń - Bydgoszcz, Koluszki - Częstochowa, Koniecpol - Częstochowa Stradom - Lubliniec - Fosowskie - Opole, Opole Groszowice - Błotnica Strzelecka, Inowrocław - Jabłonowo Pomorskie, Zawiercie - Dąbrowa Górnicza - Jaworzno Szczakowa, Rzeszów - Medyka, Kalety - Kluczbork - Ostrów Wlkp. - Poznań, Kościerzyna - Gdynia i Rybnik - Chałupki.

W 2016 r. spółka PLK zmodernizowała 510 km torów, wybudowała 549 rozjazdów, 65 wiaduktów, 27 przejść pod torami, 109 peronów, 200 przejazdów kolejowo-drogowych; wydatkowała na to 4,1 mld zł. W 2017 r. PLK planują wydatki inwestycyjne w wysokości 5,5 mld zł. Do września 2017 r. PLK podpisały umowy na modernizację linii kolejowych o łącznej wartości ok. 13 mld zł, a do końca wspomnianego roku planuje je zwiększyć do ponad 20 mld zł. Krajowy Program Kolejowy zakłada, że do 2023 r. wydatki inwestycyjne na infrastrukturę kolejową sięgną blisko 67 mld zł. PKP PLK liczą, że począwszy od 2018 r. wydatki na kolejową infrastrukturę będą przekraczały 10 mld zł rocznie.

Do 2016 r. wyremontowano budynki dworców m.in. w miejscowościach: Leżajsk, Chodzież, Radom, Środa Wielkopolska, Myszków, Gryfino, Świdnica Miasto, Świebodzice, Międzyrzec Podlaski, Łuków, Głowno, Stryków, Łęczyca, Chełm Miasto, Głogów, Kępno, Kluczbork, Wronki, Jarocin. Zakończono również przebudowę bądź modernizację dworców: Gdańsk
Główny, Kraków Płaszów, Sopot, Biała Podlaska, Rumia, Kościan, Nowy Sącz, Brzeg Dolny, Jaworzyna Śląska, Rawicz, Opole Główne, Oborniki Śląskie, Toruń Główny i Gliwice.

W 2017 r. PLK ogłosiły przetargi (w zróżnicowanej formule np. zaprojektuj i zbuduj) lub podpisały umowy na przebudowę linii o łącznej długości 2024 km, m.in.: Swarzędz - Konin - Kutno - Sochaczew (237 km), Poznań Wschodni - Trzemeszno (54 km; zakończona), Ostrowy - Otłoczyn (82,3km), Warszawa Włochy Grodzisk Mazowiecki (26,5 km), Warszawa Zachodnia - Gołąbki - Warszawa Gdańska, Siedlce - Terespol (116,6 km), Otwock - Puławy - Lublin (147,4 km), Lublin - Stalowa Wola Rozwadów (102,7km), Grybów Kamionka Wielka (19 km), Czachówek Południowy Warka - Radom (63 km), Poznań - Piła (92,5km), Jaworzno Szczakowa - Trzebinia (31,7 km), Krzeszowice - Kraków Główny (25,7km), Kraków Główny Rudzice (24,8 km), Kraków Płaszów - Podbory Skawińskie (19,4 km), Skawina - Sucha Beskidzka (46,2 km), Chabówka - Zakopane (43,3km), Łódź Kaliska - Zduńska Wola (42,3 km), Sadowne - Małkinia - Czyżew (38,9 km), Białystok - Bielsk Podlaski (46,1 km), Lewki - Hajnówka (25,8km), Ełk - Szczytno (112 km), Jamielnik - Olsztyn (74,8 km), Działdowo - Nidzica - Olsztyn (81,1 km), Nowa Wieś Wielka - Maksymilianowo $(33,4 \mathrm{~km})$, Częstochowa - Chorzew Siemkowice (48,3 km), Częstochowa - Zawiercie (42,2km), Racibórz - Krzyżanowice (9km), Bierawa - Nędza (16,1 km), Chybie - Żory - Rybnik - Nędza (60 km), Dąbrowa Górnicza Towarowa - Dąbrowa Górnicza Wschodnia / Kozioł (10km), Trzebinia Oświęcim (25,2 km), Oświęcim - Czechowice Dziedzice (20 km), Czempiń - Leszno (37,2 km), Leszno - Rawicz (32,7 km), Węgliniec - Zgorzelec (24,5km; elektryfikacja), Rudna Gwizdanów - Lubin - Legnica (36 km), Grabowno Wielkie - Zduny, Drzeńsko - Kostrzyn (27,4km), Wołów - Małowice (23km), Szczecin Główny - Szczecin Gumieńce (4,7 km), Szczecinek Słupsk - Ustka (70,7 km), Szczecinek - Runowo Pomorskie (88,2 km), Gardeja - Kwidzyn - Sztum - Malbork (56,1 km), Opole - Nysa (48,7 km); Boguchwała - Czudec (12 km); łącznic: Kraków Zabłocie - Kraków Krzemionki (w końcowej fazie budowy), Włoszczowa Płn. - Czarnca; stacji kolejowych: Gdańsk Główny, Szczecin Główny, Rzeszów Główny, Jelenia Góra, Kłodzko Główne, Legnica, Warszawa Główna Osobowa, Wałbrzych Śródmieście, Wałbrzych Szczawienko, Świebodzice, Zakopane; systemu ERTMS/ETCS na liniach: Węgliniec - Legnica (poziom 2) - Wrocław Opole, Grodzisk Maz. - Opoczno Płd. Włoszczowa Płn. - Psary - Zawiercie (CMK; poziom 1), Kunowice - Poznań - Kutno - Warszawa - Siedlce - Terespol (poziom 2), Łowicz - Łuków (poziom 1), Kraków Podłęże - Rzeszów (poziom 2). 


\section{Rozbudowa kolei aglomeracyjnych}

Znaczącą pozycję na rynku przewozów pasażerskich zajmuje obsługa aglomeracji miejsko-przemysłowych. W przypadku Polski regularną obsługę transportową aglomeracji prowadzą: Szybka Kolej Miejska w Trójmieście (Pruszcz Gdański - Gdańsk - Sopot Gdynia - Wejherowo), Warszawska Kolej Dojazdowa (Warszawa - Pruszków - Grodzisk Mazowiecki) wraz z Kolejami Mazowieckimi na odcinkach podmiejskich oraz kształtująca swój układ połączeń Łódzka Kolej Aglomeracyjna (Zgierz - Łódź Kaliska). W 2015 r. utworzono Krakowską Kolej Aglomeracyjną, głównie dla obsługi lotniska w Balicach za pomocą linii Wieliczka - Kraków Główny - Lotnisko Balice. W 2017 r. PLK podpisały umowy na modernizacje linii kolejowych w obrębie węzła kolejowego w Szczecinie celem utworzenia Szczecińskiej Kolei Metropolitarnej. Potencjalne i wciąż niezrealizowane możliwości w tym zakresie mają aglomeracje: górnośląska, wrocławska i poznańska. W konurbacji górnośląskiej gęsta i dziś ekstensywnie wykorzystywana sieć połączeń kolejowych może stanowić podstawę budowy szybkiej kolei aglomeracyjnej. W przeszłości takie próby już podejmowano, chociażby budowany w latach 80. XX wieku Kolejowy Ruch Regionalny (KRR), na potrzeby, którego budowano drugą parę torów na średnicowym dla aglomeracji odcinku Katowice - Chorzów Batory - Ruda Chebzie - Zabrze. Inwestycję porzucono, a już ułożone na niektórych odcinkach tory zdemontowano. Nieudany start Kolei Śląskich, ograniczający swoją ofertę przewozową tylko dla linii Gliwice - Zabrze - Katowice - Sosnowiec - Zawiercie, powoduje nieufność decydentów wobec powrotu jakiejkolwiek koncepcji budowy kolei aglomeracyjnej w GOP. Perspektywa nowego budżetu unijnego na lata 2014-2020 jest ostatnią szansą wprowadzenia do regionalnego programu operacyjnego województwa śląskiego budowy proekologicznej Górnośląskiej Kolei Metropolitalnej zintegrowanej z dobrze rozbudowanymi systemami komunikacji miejskiej w konurbacji górnośląskiej. Budowa wydzielonej dla ruchu aglomeracyjnego dodatkowej pary torów - jak wykazały doświadczenia próby budowy KRR w latach 80. XX wieku - dla newralgicznej dla konurbacji osi przewozowej Gliwice - Zabrze - Ruda Śląska - Katowice - Sosnowiec jest możliwa. Zapotrzebowanie na szybkie kolejowe przewozy w konurbacji górnośląskiej pozostaje wciąż potencjalnie duże, czego przykładem są perturbacje związane z funkcjonowaniem Kolei Śląskich i sukces tego typu przewozów realizowanych przez Koleje Mazowieckie w aglomeracji warszawskiej czy przez Szybką Kolej Miejską w Trójmieście. Obecnie ekstensywnie eksploatowana gęsta sieć kolejowa konurbacji górnośląskiej stwarza wprost idealne warunki do kreowania sieci połączeń szybkiej kolei regionalnej przede wszystkim na podstawie wspomnianej już linii równoleżnikowej Gliwice - Zabrze - Chorzów Batory - Sosnowiec - Dąbrowa Górnicza z odgałęzieniem w kierunku Mysłowic i Jaworzna oraz przyszłym południkowym przebiegiem trasy Pyrzowice (lotnisko) / Tarnowskie Góry Bytom - Chorzów - Katowice - Tychy. Włączenie w układ Górnośląskiej Kolei Metropolitalnej portu lotniczego Katowice Pyrzowice jest szansą na utworzenie takiej kolei aglomeracyjnej, a także na uporządkowanie systemu transportu kolejowego w konurbacji górnośląskiej. W przygotowaniu jest projekt odtworzenia linii kolejowej Tarnowskie Góry - Mierzęcice - Zawiercie przebiegającej w sąsiedztwie intensywnie rozbudowywanych terminali zarówno pasażerskich, jak i towarowych lotniska Pyrzowice.

Jest koniecznością, by w trakcie dużych inwestycji modernizacyjnych, prowadzonych zarówno obecnie, jak i w przyszłości, rezerwować teren i przygotowywać go pod przyszłą zabudowę dla dodatkowych par torów dla ruchu aglomeracyjnego. Tak pomyślano m.in. przy projektowaniu linii na potrzeby rozpoczynającej się modernizacji magistrali Rail Baltica na odcinku Zielonka - Wołomin - Tłuszcz w rejonie Warszawy. Realizowane kolejne duże projekty modernizacyjne, m.in. linii Warszawa - Radom i Warszawa - Lublin, również powinny uwzględniać kwestie obsługi podmiejskich przewozów pasażerskich w rejonie Warszawy. Podobnie uczyniono w przypadku rozpoczętej w 2017 r. modernizacji linii Kraków Główny - Rudzice, gdzie planowana jest budowa dodatkowej pary torów dla potrzeb ruchu aglomeracyjnego.

Przykładem modernizacji istniejącego układu kolejowego na potrzeby miasta i jego strefy podmiejskiej jest budowa Łódzkiej Kolei Aglomeracyjnej. Pierwszym elementem kształtowania systemu kolei aglomeracyjnej na terenie aglomeracji łódzkiej była modernizacja trasy z Łodzi do Łowicza, która usprawniła dojazdy koleją do Łodzi. Odcinek między Zgierzem a Łowiczem został zmodernizowany przez Polskie Linie Kolejowe w 2011 r. Prace prowadzone kosztem ok. $65 \mathrm{mln}$ zł umożliwiły wznowienie ruchu pociągów pasażerskich na tej liczącej $47 \mathrm{~km}$ trasie. Zakres prac budowlanych objął m.in. kompleksową wymianę nawierzchni torowej oraz modernizację 43 przejazdów drogowych. Wykonanie tych robót pozwoliło na przywrócenie na wyremontowanym odcinku linii kolejowej prędkości 90 km/h. Łódzka Kolej Aglomeracyjna to szansa na rozwój transportu w całym regionie łódzkim. Pasażerowie korzystają już z 13 nowych i zmodernizowanych peronów, przy których zatrzymują się pociągi aglomeracyjne. $\mathrm{W}$ ramach realizowanego projektu powstanie łącznie 8 
nowych i 9 zmodernizowanych przystanków i stacji. Każdy przystanek będzie przystosowany do potrzeb niepełnosprawnych, podróżnych z cięższym bagażem czy rodziców z dziećmi w wózkach. Montowane są na nich wiaty, oświetlenie i stojaki na rowery. Inwestycja obejmująca odcinki czterech linii kolejowych z Łodzi do Łowicza i Kutna oraz ze stacji Łódź Kaliska do stacji Łódź Chojny i Łódź Widzew zakończona została w 2013 r. Wartość projektu przekracza $42 \mathrm{mln}$ zł netto. Dotacje unijne przyznane z Regionalnego Programu Operacyjnego Województwa Łódzkiego pokryły $85 \%$ kosztów (36 mln zł netto). Kolejne 6,4 mln zł pochodzi od podmiotów współrealizujących inwestycję, w tym spółek Polskie Linie Kolejowe i PKP oraz miasta Łódź oraz gminy Zgierz.

Rozszerzeniem budowy Łódzkiej Kolei Aglomeracyjnej jest również rewitalizacja linii kolejowej Łódź Widzew - Zgierz. W połowie 2013 r. rozpoczęto tam wstępne roboty budowlane. Inwestycja obejmie przebudowę torów na długości 12 km. Po zakończeniu prac czas przejazdu pociągiem aglomeracyjnym z Łodzi Widzewa do stacji Zgierz wyniesie ok. 15 min, a maksymalna prędkość pociągów zwiększy się do 100 km/h. Podróżni będą mogli ponownie korzystać z trzech przebudowanych przystanków: Łódź Stoki, Łódź Radogoszcz i Łódź Arturówek, od wielu lat wyłączonych z eksploatacji. Istotną częścią inwestycji jest przebudowa pięciu przejazdów kolejowych w ciągu ulic. Część z nich zostanie wyposażona w samoczynną sygnalizację świetlną i półrogatki. Prace związane z rewitalizacją linii ze Zgierza do stacji Łódź Widzew obejmą również roboty na 11 obiektach inżynieryjnych, takich jak wiadukty, mosty czy przepusty. Wspomniane prace zrealizowano w latach 2013 2014. Planowane jest rozszerzenie połączeń tej kolei m.in. w kierunku Opoczna, gdzie już przystąpiono do modernizacji stacji, a prowadzącą doń linię planuje się zelektryfikować.

\section{Połączenia kolejowe portów lotniczych}

Po okresie intensywnej rozbudowy portów lotniczych w Polsce przyszedł czas na ich skomunikowanie z centrami pobliskich miast za pomocą kolei. Takiej inwestycji w 2012 r. doczekał się jako pierwszy międzynarodowy port lotniczy Warszawa Okęcie, następnie otwarty w grudniu 2012 r. port lotniczy Lublin Świdnik, lotnisko Szczecin Goleniów, a ostatnio Kraków Balice. W wielu przypadkach zabrakło jednakże odpowiedniego planowania połączeń pasażerskich, w związku z tym początkowo mała liczba pasażerów korzystała z pociągów kursujących w relacjach lotnisko - miasto. Liczba pasażerów nie jest jedynym wyznacznikiem zasadności budowania połączenia kolejowego do lotniska. Równie ważne za- gadnienia to: odległość od głównej aglomeracji obsługiwanej przez lotnisko, rodzaj taboru, jakość dojazdu innymi środkami transportu, struktura przewoźników (przewaga lotniczych linii niskokosztowych) i siatka ich połączeń (krótki i długi dystans). Nie każdy typ połączenia kolejowego jest odpowiedni dla każdego lotniska. Dlatego funkcjonują m.in.: airport express (np. Arlanda Express, Heathrow Express), pociągi podmiejskie, pociągi regionalne, jak również połączenia długodystansowe (np. szybka kolej we Frankfurcie nad Menem).

Próby włączenia linii kolejowych do obsługi rozbudowywanych w ramach sieci TEN-T portów lotniczych w Polsce podejmowano już w latach 2007-2013. Zrealizowano m.in.: 1. budowę linii i podziemnego terminalu kolejowego dla lotniska Warszawa Okęcie; 2. wydłużono i zelektryfikowano linię w kierunku zbudowanego nowego lotniska Lublin Świdnik; 3. zbudowano od podstaw w śladzie istniejącej linii Gdańsk - Rębiechowo - Kokoszki dwutorową, niestety pozbawioną trakcji elektrycznej, Pomorską Kolej Metropolitarną; 4. przystąpiono do budowy i modernizacji połączenia kolejowego lotniska w Balicach z Krakowem; 5. opracowano koncepcję i przystąpiono do rozbudowy Łódzkiej Kolei Aglomeracyjnej o połączenie z lotniskiem Łódź Lublinek; 6. województwo zachodniopomorskie wybudowało przystanek pasażerski na lotnisku Szczecin Goleniów i zmodernizowało linię kolejową Goleniów - Kołobrzeg przebiegającą w sąsiedztwie tegoż lotniska; 7. podobnie województwo warmińsko-mazurskie w ramach programu operacyjnego zmodernizowało linię kolejową w kierunku lotniska pod Szczytnem, a w najbliższych latach planowana jest modernizacja linii kolejowej w kierunku Ełku.

Dnia 7 maja 2013 r. konsorcjum firm Budimex (lider) i Ferrovial Agroman (partner) podpisało umowę na projekt i budowę Pomorskiej Kolei Metropolitalnej w Gdańsku. Umowa miała wartość 582,2 mln zł netto. Prace budowlane trwały do końca kwietnia 2015 r. W ramach kontraktu zbudowano: 17 km odcinek dwutorowej linii kolejowej od stacji Gdańsk Wrzeszcz przez Port Lotniczy im. Lecha Wałęsy w Rębiechowie do połączenia z linią kolejową Gdynia - Kościerzyna; 1,4 km odcinek jednotorowej łącznicy PKM z linią kolejową Gdynia - Gdańsk - Tczew; 8 przystanków pasażerskich, stację techniczną do zmiany kierunku jazdy pociągów; budynek Lokalnego Centrum Sterowania Ruchem; 16 wiaduktów kolejowych, 7 wiaduktów drogowych, 1 estakadę w rejonie lotniska, 5 przejść nad torami, kładki dla pieszych, przepusty oraz przejścia dla zwierząt. Pomorska Kolej Metropolitalna usprawniła regionalny transport kolejowy, a Gdańsk i Gdynia zostały połączone z portem lotniczym Rębiechowo. Ponadto Gdańsk uzyskał połącze- 
nie kolejowe z Kartuzami, Kościerzyną oraz obwodowe w kierunku Gdyni (Osowa). Pomorską Kolej Metropolitalną zlokalizowano na całkowicie przebudowanym torowisku po dawnej linii z Gdańska w stronę Kokoszek. Po wyburzeniu wszystkich starych obiektów (łącznie 14) zrealizowano roboty związane ze wzmocnieniem gruntu pod nowe obiekty mostowe i nasypy kolejowe. Zbudowano także drogi dojazdowe i technologiczne o łącznej długości ok. 10 km. Linia PKM w grudniu 2014 r. była już przejezdna na odcinku od lotniska do Strzyży. Od marca 2015 r. cała linia PKM była gotowa. Połączenie linii PKM z liniami PLK, zarówno od strony Gdańska Wrzeszcza, jak i Rębiechowa (wraz z budową drugiego toru pomiędzy Rębiechowem a stacją Gdańsk Osowa), zrealizowały PLK.

PKP Polskie Linie Kolejowe 26 września 2013 r. podpisały umowę z firmą Astaldi na roboty budowlane i opracowanie projektów wykonawczych modernizacji połączenia kolejowego z Krakowa do Międzynarodowego Portu Lotniczego Balice. Nowe, zelektryfikowane i wydłużone połączenie kolejowe zostało uruchomione w 2015 r. Projekt inwestycyjny objął budowę: drugiego toru na odcinku Kraków Mydlniki - Kraków Balice, wydłużenie połączenia do głównego terminalu lotniskowego o ok. 500 m, a także elektryfikację linii. Inwestycja umożliwiła szybki i sprawny przejazd pomiędzy centrum Krakowa a lotniskiem w Balicach. Efektem prac jest również łatwiejszy dostęp do transportu kolejowego dla mieszkańców dzielnic sąsiadujących z portem lotniczym. Na trasie połączenia powstały bowiem trzy przystanki kolejowe: Kraków Uniwersytet Rolniczy, Kraków Zakliki, Kraków Krzyżówka. Nowe obiekty zostały wyposażone w wiaty, ławki i oświetlenie oraz perony przystosowane do potrzeb osób z ograniczonymi możliwościami poruszania się. Istniejące przystanki Kraków Łobzów i Kraków Balice zostały zmodernizowane. Wartość tej inwestycji przekroczyła $240 \mathrm{mln}$ zł i jest efektem realizacji projektu POliŚ refinansowanego przez Unię Europejską.

W ramach projektu "Rewitalizacja i modernizacja linii kolejowych Olsztyn - Szczytno - Szymany jako kolejowe połączenie modernizowanego lotniska w Szymanach z Olsztynem (etap I)" ułożono nowe tory na linii z Olsztyna do Szczytna i odnowiono linię na odcinku Szczytno - Szymany. Modernizacja lub wymiana objęła 113 obiektów inżynieryjnych, w tym 2 mosty i 4 wiadukty. Poprawiono standard techniczny 37 przejazdów kolejowo-drogowych i dróg dojazdowych, a 12 skrzyżowań drogowo-kolejowych wyposażono w urządzenia samoczynnej sygnalizacji przejazdowej. Zastosowane rozwiązania zwiększają bezpieczeństwo ruchu drogowego i kolejowego. W celu obsługi podróżnych przebudowano perony stacji w miejscowościach: Klewki, Marcinkowo, Pasym, Grom, Szczytno, Siódmak i Szymany. Obiekty wyposażone są w nowe wiaty i oświetlenie oraz dostosowane do obsługi osób niepełnosprawnych. W kwietniu 2013 r. PKP Polskie Linie Kolejowe podpisały umowę na opracowanie dokumentacji projektowej dla drugiego etapu inwestycji, który obejmie m.in. budowę: 2 km linii do terminalu Portu Lotniczego "Mazury" w Szymanach, peronu przy terminalu lotniczym i Lokalnego Centrum Sterowania w Szczytnie. Realizacja drugiego etapu budowy planowana jest na lata 2014-2015. Końcowym efektem inwestycji było utworzenie połączenia kolejowego Olsztyna z lotniskiem w Szymanach oraz podniesienie prędkości pociągów na tej linii do $100 \mathrm{~km} / \mathrm{h}$, co pozwoliło skrócić podróż na tej trasie do ok. 45 min.

W maju 2013 r. PKP Polskie Linie Kolejowe otworzyły nową linię kolejową prowadzącą do portu lotniczego Szczecin Goleniów i zmodernizowały trasę Goleniów - Kołobrzeg. Po modernizacji połączenia pociągi mogą się tam poruszać z szybkością maksymalną 120 km/h, co oznacza skrócenie czasu przejazdu ze Szczecina na lotnisko do 40 minut, a z Kołobrzegu - do 90 minut. Na odcinku Goleniów - Kołobrzeg wykonano kompleksową wymianę nawierzchni na długości ponad $16 \mathrm{~km}$. W ramach inwestycji wyremontowano wiadukt w Gryficach oraz przebudowano urządzenia sterowania ruchem kolejowym. Zmodernizowano perony stacji w Baszewicach, Gąbinie, Głowaczewie, Nowogardzie, Wyszomierzu, Bieczynie Pomorskim i Starym Borku. Nowe wiaty peronowe zbudowano w Gąbinie, Starym Borku, Baszewicach, Głowaczewie, Bieczynie Pomorskim, Wyszomierzu i Mostach. Pociągi jadące do przystanku obok lotniska korzystają z nowych torów na długości ok. 4 km. Budowa łącznicy do portu lotniczego objęła również montaż nowych rozjazdów, wykonanie nasypów oraz budowę systemu sterowania ruchem kolejowym. Całkowity koszt inwestycji realizowanej w ramach Regionalnego Programu Operacyjnego Województwa Zachodniopomorskiego wyniósł $55 \mathrm{mln}$ zł (netto), w tym budowa samej łącznicy - 16,3 mln zł.

\section{Likwidacja deficytowych linii kolejowych}

Na podstawie danych GUS zestawionych w tab. 1 można stwierdzić, że tylko w latach 2003-2016 długość sieci kolejowych uległa skróceniu o 1533 km. Likwidacji uległa całkowicie m.in. sieć kolei wąskotorowych o długości ok. 400 km². Uwzględniając tą

4 Część linii wąskotorowych jest nadal użytkowana w formie kolei turystycznych, co pomijają statystyki GUS. Dokładne zestawienia użytkowanych kolei wąskotorowych możemy odnaleźć m.in. w opracowaniach A. Ciechańskiego. 
wielkość dochodzimy do wniosku, że we wspomnianym okresie zawieszono bądź zlikwidowano ruch kolejowy na ok. 1034 km normalnotorowych linii kolejowych. W tej liczbie znalazły się zarówno linie dwui jednotorowe, jak i linie wyposażone w trakcje prądu stałego 3 kV. Z linii zlikwidowanych, na których zdemontowano trakcję elektryczną można wymienić przykładowe dwutorowe trasy tworzące niegdyś tzw. VIII wylot z Górnego Śląska: Kluczbork - Fosowskie wraz z obwodnicą kolejową Kluczborka, Zabrze Mikulczyce - Tworóg Brynek i Zabrze Biskupice - Zabrze Mikulczyce - Pyskowice czy jednotorową Krokowa - Żarnowiec

Dnia 15 lutego 2013 r. PKP Polskie Linie Kolejowe podjęły decyzję o czasowym wyłączeniu z ruchu ok. 2 tys. km linii kolejowych. Po trwających prawie pół roku analizach, obejmujących ponad 500 odcinków liczących przeszło 7 tys. km, wybrano ostrożny wariant optymalizacji sieci kolejowej. Szacowane oszczędności mogą wynieść rocznie ok. 60-80 mln zł. Przygotowywane rozwiązanie przyczyni się do stabilizacji stawek dostępu do infrastruktury oraz przeznaczenia dodatkowych środków na utrzymanie linii intensywnie eksploatowanych przy znikomych kosztach społecznych. Jednocześnie spółka zapowiada kontynuację konsultacji z samorządami i przewoźnikami, które krytycznie odniosły się do planów likwidacji linii kolejowych.

PKP Polskie Linie Kolejowe zarządzały wówczas siecią ponad 21600 km linii kolejowych, których wykorzystanie było bardzo zróżnicowane. Odcinki od lat nieczynne to blisko $2200 \mathrm{~km}$ linii. Analizie poddano 458 odcinków linii kolejowych o łącznej długości prawie $7300 \mathrm{~km}$.

Rozbudowana metodologia badań obejmowała historyczne, obecne, jak również przewidywane w najbliższych latach przychody pozyskiwane od przewoźników oraz koszty prowadzenia ruchu i utrzymania torów. Brała pod uwagę także szereg czynników społeczno-ekonomicznych, takich jak: liczba ludności na obszarze dostępności komunikacyjnej, wpływ ruchu na badanym odcinku na transport pasażerski i towarowy w regionie, dostępność i koszt alternatywnych środków transportu, maksymalna dzienna liczba osób korzystających z kolei, czynniki sezonowe wynikające ze wzmożonego ruchu turystycznego, perspektywy gospodarcze terenu, lokalne plany inwestycyjne oraz szereg innych.

Badania doprowadziły do zidentyfikowania ok. 300 nierentownych odcinków linii kolejowych liczących prawie 4 tys. km długości, z których ponad 30, mimo braku rentowności, uznawanych jest za niezbędne do pracy eksploatacyjnej lub które cechują się wysokim rozwojem społeczno-gospodarczym. Natomiast pozostałe linie wykazują głęboką stratę przy niewielkim stopniu oddziaływania na otoczenie, stwarzając tym samym potencjał do uwolnienia wysokich kosztów prowadzenia ruchu i eksploatacji tras kolejowych.

Jako etap dalszych konsultacji w procesie konstruowania rocznego rozkładu jazdy 2013/2014 przewoźnicy otrzymali zaktualizowaną mapę połączeń zakładającą wyłączenie z ruchu 90 odcinków o łącznej długości blisko 2000 km. Równolegle kontynuowano rozmowy z samorządami i środowiskami gospodarczymi na temat utrzymania niektórych linii.

Zawieszenie ruchu nie oznacza fizycznej likwidacji linii, lecz jedynie zaprzestanie prowadzenia prac utrzymaniowych i zamknięcie posterunków ruchu wraz z uwolnieniem związanych z tym etatów pracowniczych. Roczne oszczędności z tym związane mogą sięgnąć nawet $100 \mathrm{mln}$ zł i zostać przekazane na utrzymanie linii mających większe znaczenie, a tym samym przyczynić się do poprawy ich parametrów i zwiększenia korzyści dla pasażerów. Zawieszenie ruchu jest procesem odwracalnym i w przypadku nowych okoliczności gospodarczych istnieje szansa na jego szybkie przywrócenie.

\section{Analiza modernizacji sieci kolejowej Polski}

Po okresie przemian społeczno-ustrojowych w Polsce w latach 1990-2017 sieć kolejowa Polski przechodziła różne fazy rozwojowe. Lata 90. XX wieku to okres stagnacji w rozwoju sieci kolejowej. Zmienia się formuła zarządzania PKP, dochodzi do podziału PKP na spółki zależne, w tym zgodnie z zaleceniami UE następuje oddzielenie infrastruktury od operatorów w przewozach pasażerskich i towarowych. Powstaje m.in. spółka Polskie Linie Kolejowe, która zarządza infrastrukturą liniową kolei. W latach 90. XX wieku dochodzi do drastycznego spadku przewozów kolejowych, którego pośrednim efektem jest regres sieci kolejowej przejawiający się zawieszaniem przewozów i likwidacją linii kolejowych. Poza niezbędnymi robotami utrzymaniowymi na liniach nie prowadzi się praktycznie żadnych nowych inwestycji. Niewielkie nakłady na utrzymanie sieci kolejowej powodują, że postępuje dekapitalizacja linii i spadek prędkości eksploatacyjnej nawet do 20-40 km/h. Po 1990 r. a przed akcesją Polski do UE jedyną kompleksowo prowadzoną inwestycją liniową była modernizacja magistrali o znaczeniu międzynarodowym na trasie Rzepin - Poznań - Konin - Kutno - Łowicz - Sochaczew - Warszawa - Siedlce - Łuków - Terespol. W założeniu linię modernizowano do technicznych parametrów paneuropejskich, pozwalających osiągnąć prędkość $160 \mathrm{~km} / \mathrm{h}$ dla pociągów pasażerskich i 120 km/h dla pociągów towarowych. Linię modernizowano odcinkami. W pierwszej kolejności skupiono się 
na odcinku Poznań - Konin - Kutno - Łowicz - Sochaczew - Warszawa. Przy czym koncentrowano się na łatwiejszych do prowadzenia pracach na odcinkach szlakowych poza węzłami. Modernizację torów stacyjnych pozostawiano na później, w efekcie niektóre stacje pozostają nadal nie zmodernizowane. W kolejnej fazie prowadzono modernizację odcinka Poznań - Zbąszynek - Rzepin oraz przystąpiono do przebudowy poznańskiego węzła kolejowego. Ostatnia faza modernizacji objęła odcinki zlokalizowane na wschód od Warszawy, tj. linię Warszawa Wschodnia - Siedlce - Łuków - Terespol. Dla końcowego odcinka magistrali Łuków - Biała Podlaska - Terespol ograniczono parametry modernizacyjne do prędkości maksymalnej 140 km/h. Modernizacja wspomnianej linii przedłużyła się znacznie w czasie, stąd też niektóre fragmenty magistrali są nadal modernizowane (np. przebudowa systemów sterowania ruchem na odcinku Siedlce - Łuków - Terespol); nie zakończono również modernizacji wszystkich stacji zlokalizowanych na zachodnim i środkowym odcinku linii. Ostatecznie przetarg na modernizację stacji ogłoszono dopiero w 2017 r.

Po 2000 r. przystąpiono do modernizacji linii kolejowej Wrocław - Brzeg - Opole. Tu również modernizacja się przedłużała. W pierwszej kolejności przebudową objęto tory szlakowe, a dopiero później układy torowe stacji: Wrocław Brochów, Oława, Brzeg, Lewin Brzeski i Opole Zachodnie. Na pozostałych licznych stacjach linii pozostawiono jedynie główne tory szlakowe, likwidując dotychczasowe funkcje manewrowe i przeładunkowe. Równocześnie po 2005 r. podjęto modernizację linii Wrocław - Legnica - Węgliniec, którą w ostatnich latach doprowadzono do stacji granicznych w Bielawie Dolnej i Zgorzelcu. Moim zdaniem decyzja o modernizacji końcowego, przygranicznego fragmentu linii była przedwczesna. Dla sieci kolejowej Polski o wiele korzystniejsza byłaby przebudowa jej newralgicznego odcinka Opole - Katowice - Kraków, znacznie obciążonego przewozami, niż peryferyjnie położonego i mającego marginalne znaczenie w przewozach krajowych odcinka Legnica - Węgliniec - Zgorzelec.

W okresie 1990-2010 prace modernizacyjne zasadniczo ograniczono do trzech linii magistralnych: Rzepin - Zbąszynek - Poznań - Konin - Warszawa - Siedlce - Terespol, Warszawa - Opoczno - Włoszczowa Północ - Zawiercie (CMK) oraz do fragmentu południowej magistrali na odcinku Zgorzelec - Legnica - Wrocław - Brzeg - Opole.

Po akcesji Polski do UE w 2004 r. z budżetu na lata 2007-2013 w pierwszym okresie rozpoczęto modernizację do parametrów paneuropejskich tylko linii kolejowej Warszawa Wschodnia - Ciechanów - Mława - Iława - Malbork - Tczew - Gdańsk - Gdynia.
Przedłużające się roboty budowlane spowodowały, że efekt modernizacyjny osiągnięto dopiero pod koniec 2014 r., głównie celem wprowadzenia na linii szybkich pociągów pasażerskich Pendolino. Omawiając wspomnianą w sumie nieudaną, bo przedłużającą się w czasie, inwestycję, można odnieść wrażenie, że korzystniejszym rozwiązaniem byłby powrót do zarzuconej w końcu lat 70. XX wieku koncepcji budowy przedłużenia CMK w kierunku aglomeracji gdańskiej. Budowa północnego fragmentu CMK na trasie Grodzisk Mazowiecki - Płock - Toruń - Grudziądz Gdańsk prawdopodobnie byłaby nieznacznie droższa od kosztownej i trudnej technicznie modernizacji starej linii Warszawa - Iława - Malbork - Gdańsk. Północne odgałęzienie CMK, zbudowane zgodnie z parametrami linii kolejowych wielkich szybkości, pozwoliłoby uzyskać zdecydowaną poprawę obsługi transportowej dotychczas wykluczonych w tym zakresie miast zlokalizowanych w dolinie Wisły (Płock, Toruń, Bydgoszcz, Grudziądz) oraz ukształtować główną perspektywiczną oś kolei dużych prędkości w kraju (CMK na trasie konurbacja górnośląska - aglomeracja warszawska - aglomeracja gdańska).

Wydłużające się i źle zorganizowane prace modernizacyjne na liniach kolejowych przyniosły również negatywne skutki w absorpcji środków unijnych na inwestycje infrastrukturalne. Polska próbowała przeznaczyć niewykorzystane środki z inwestycji kolejowych na sprawniej przebiegające inwestycje drogowe. Pomysły te zostały zablokowane przez struktury zarządcze UE, gdzie nadal obowiązuje zasada wsparcia proekologicznych gałęzi transportu, do których jest zaliczana zarówno kolej, jak i żegluga śródlądowa i morska (60\% środków na drogi, pozostałe $40 \%$ na kolej i żeglugę). Takie stanowisko komisji UE i ewentualna utrata dofinansowania spowodowały powrót do inwestycji kolejowych w Polsce i znalezienie nowej formuły organizacyjnej i finansowej dla ich zdecydowanego przyspieszenia. Przede wszystkim, obok finansowanych z budżetu UE gruntownych prac modernizacyjnych na liniach kolejowych o znaczeniu międzynarodowym, wysunięto koncepcję rewitalizacji magistral o podstawowym znaczeniu w przewozach pasażerskich i towarowych. Rewitalizacja - mówiąc w uproszczeniu - polega na przywróceniu projektowych parametrów technicznych linii pozwalających osiągnąć szybkości rzędu 100-120 km/h. Według tych założeń przeprowadzono modernizację m.in. linii: Toruń - Bydgoszcz, Koluszki - Częstochowa, Koniecpol - Częstochowa Stradom - Lubliniec - Fosowskie - Opole, Opole Groszowice - Strzelce Opolskie - Pyskowice - Gliwice - Katowice czy Poznań - Krzyż. Przyspieszenie prac modernizacyjnych przypadło na trudne lata 2012-2014 związane z końcowym okresem wydawania środków z obecnego 
budżetu UE. Przebiegająca opieszale modernizacja linii kolejowych to nie tylko wynik złej organizacji i przyjętych błędnych założeń w etapowaniu i realizacji inwestycji infrastrukturalnych, lecz również efekt trudności na rynku budowlanym. Niektóre wyspecjalizowane firmy z kolejowej branży budowlanej w latach 2010-2012 miały trudności finansowe i wykonawcze, co przekładało się na opóźnienia w realizacji inwestycji kolejowych.

Na podstawie map ukazujących obciążenie sieci kolejowej Polski w przewozach pasażerskich i towarowych można sformułować zasady dalszego etapowania inwestycji liniowych na polskiej sieci kolejowej. Zasadniczo prace modernizacyjne winny objąć przede wszystkim linie magistralne zgłoszone przez nasz kraj jako podstawowe w umowach: AGC - obejmującej przewozy pasażerskie i AGTC - obsługującej przewozy towarowe. Zauważalne jest na sieci PLK nakładanie się tych dwóch różnych pod względem eksploatacyjnym rodzajów przewozów. Przewozy pasażerskie winny być prowadzone lekkimi składami pociągów pasażerskich, lecz ze znaczną szybkością rzędu $120-160 \mathrm{~km} / \mathrm{h}$. Natomiast dla przewozów towarowych mniejsze znaczenie ma szybkość, która może być ograniczona do $80-120 \mathrm{~km} / \mathrm{h}$, ważne są natomiast nośność szlaku i niezakłócony przejazd. Ciężkie, poruszające się powoli składy towarowe o masie brutto do 3200-3600 t wpływają ponadto destrukcyjnie na torowisko i przepustowość szlaku. Przeciwstawne cechy ruchu pasażerskiego i towarowego wymuszają specjalizację linii przeznaczonych dla przewozów pasażerskich (np. CMK Grodzisk Mazowiecki - Opoczno - Zawiercie) i towarowych (np. magistrala węglowa Tarnowskie Góry - Herby - Karsznice - Bydgoszcz - Gdańsk). Podział i specjalizacja linii wraz z przypisaniem linii do określonego typu ruchu pasażerskiego bądź towarowego powinny być pogłębione. Dla tras obsługujących szybkie przewozy pasażerskie winny być wyznaczone zastępcze linie dla prowadzenia niezakłóconego ruchu towarowego. Przykładowo, dla trasy Rzepin - Zbąszynek - Poznań - Kutno - Warszawa - Siedlce - Terespol, dostosowanej do szybkości $160 \mathrm{~km} / \mathrm{h}$, taki alternatywny szlak można zbudować na podstawie linii Rzepin / Tuplice - Głogów - Leszno - Ostrów Mazowiecki - Zduńska Wola - Łódź Olechów - Koluszki - Tomaszów Mazowiecki - Radom - Dęblin - Łuków. Dla istotnej w przewozach pasażerskich linii Katowice - Gliwice - Opole - Wrocław - Leszno - Poznań - Krzyż - Szczecin taką alternatywę, zarówno w przeszłości, jak i obecnie, stanowi tzw. magistrala nadodrzańska na trasie Gliwice - Kędzierzyn-Koźle - Opole Groszowice - Jelcz Miłoszyce - Wrocław Brochów - Głogów - Kostrzyn - Szczecin. Podobnie jest z trasą magistrali węglowej
Tarnowskie Góry - Herby - Karsznice - Bydgoszcz Gdańsk, która już od lat 30. XX wieku była najważniejszą linią towarową Polski. Utrata parametrów technicznych wskutek braku remontów oraz nakładanie się przewozów pasażerskich na północnym odcinku magistrali Bydgoszcz - Tczew - Gdańsk powodują, że linia ta traci swoje pierwszorzędne znaczenie w przewozach towarowych na osi GOP - zespół portowy Gdańsk - Gdynia. Również w tym przypadku należy się zastanowić nad koncepcją powrotu części ruchu towarowego na zbudowany właśnie na potrzeby magistrali węglowej odcinek Maksymilianowo - Kościerzyna - Gdynia i zwolnienie w ten sposób dla szybkich przewozów pasażerskich odcinka Bydgoszcz - Tczew - Gdańsk. W tym celu należałoby linię Bydgoszcz - Kościerzyna - Gdynia docelowo wyposażyć w drugi tor i zelektryfikować.

Niekwestionowane znaczenie w przewozach pasażerskich ma także magistrala Katowice - Kraków - Tarnów - Rzeszów - Przemyśl. Obecnie linia ta jest modernizowana celem dostosowania jej do parametrów paneuropejskich w ruchu pasażerskim i towarowym. Na czas remontu linia praktycznie została wyłączona z eksploatacji. Również ta linia prowadzi ruch mieszany, w tym przewozy pasażerskie istotne dla zlokalizowanych na południu kraju znaczących ośrodków miejskich, takich jak Katowice (wraz z całą konurbacją górnośląską), Kraków, Tarnów, Rzeszów i Przemyśl. Także ruch towarowy w kierunku zespołu stacji przeładunkowych Żurawica - Medyka zlokalizowanych na granicy z Ukrainą jest znaczący. Tutaj rolę alternatywnej trasy przewozów towarowych w kierunku Ukrainy winna przejąć Linia HutniczoSzerokotorowa wraz z rozbudowywanymi terminalami przeładunkowymi w rejonie Stalowej Woli, Staszowa, Sędziszowa i Sławkowa. Ten ostatni zlokalizowany jest na wschodnim obrzeżu GOP. W celu aktywizacji linii LHS w tranzycie na osi Europa - Azja pojawiła się w ostatnim roku koncepcja przedłużenia linii szerokotorowej do portów śródlądowych systematu odrzańskiej drogi wodnej, co stworzyłoby intermodalny system logistyczny (drogi wodne - kolej szerokotorowa - drogi ekspresowe). Ze swej strony dodam, że przedłużenie LHS ze Sławkowa w kierunku portów w Gliwicach i Koźlu można poprowadzić trasami zlikwidowanych obecnie górnośląskich normalnotorowych kolei piaskowych. Część przewozów mogłyby przejąć także słabo wykorzystywane w przewozach normalnotorowe linie równoległe do LHS na trasie Przemyśl - Przeworsk - Leżajsk / Hrebenne - Zwierzyniec - Stalowa Wola - Ocice - Staszów - Sitkówka Nowiny - Jędrzejów - Tunel - Olkusz - Dąbrowa Górnicza. 
10. Perspektywiczne kierunki inwestycji kolejowych w Polsce (propozycje autorskie)

Najważniejszymi perspektywicznymi kierunkami modernizacji sieci kolejowej w Polsce winny być (tab. 6.):

- Realizacja Kolei Dużych Prędkości (KDP) Warszawa - Łódź Fabryczna - Kalisz - Wrocław / Poznań (300-350 km/h) oraz perspektywiczna budowa północnego przedłużenia CMK na trasie Warszawa - Płock - Toruń - Grudziądz - Malbork.

- Dostosowanie do prędkości 160-200 km/h linii kolejowych prowadzących przewozy pasażerskie z Warszawy do Katowic i Krakowa przez CMK, Gdańska przez Działdowo, Poznania przez Kutno, Białegostoku przez Małkinię, Bydgoszczy przez Kutno i Toruń, Szczecina przez Poznań i Krzyż oraz Lublina przez Dęblin.

- Ujednolicenie parametrów technicznych połączeń magistralnych: równoleżnikowego Zgorzelec - Legnica - Wrocław - Opole - Gliwice - Katowice - Kraków - Rzeszów - Przemyśl oraz południkowego Warszawa - Radom - Kielce - Tunel - Kraków wraz z odgałęzieniem Skarżysko-Kamienna - Sandomierz - Rzeszów.

- Modernizacja dla potrzeb ruchu towarowego i obsługi portów morskich Magistrali Węglowej Chorzów - Tarnowskie Góry - Herby Nowe - Karsznice - Bydgoszcz - Gdańsk - Gdynia z wykorzystaniem jej wariantowego odcinka północnego na trasie Bydgoszcz - Kościerzyna - Gdynia / Tczew oraz Magistrali Nadodrzańskiej na trasie Gliwice - Kędzierzyn-Koźle - Opole - Jelcz Miłoszyce - Wrocław - Głogów - Kostrzyn - Szczecin - Świnoujście.

- Początki kształtowania Magistrali Wschodniej na trasie Białystok - Lublin - Rzeszów wraz z transgranicznymi połączenia kolejowymi z Litwą (w oparciu o linie Białystok / Olsztyn - Ełk - Suwałki - Trakiszki), Ukrainą (linia Malhowice - Krościenko) i Słowacją (linia Zagórz - Łupków).
- Utworzenie alternatywnej środkowej magistrali dla przewozów towarowych na osi wschód - zachód na trasie Rzepin / Żagań - Głogów - Leszno - Ostrów - Zduńska Wola - Łodź Widzew - Koluszki - Radom - Dęblin - Łuków z połączeniami do stacji granicznych z Białorusią i Ukrainą.

- Specjalizacja linii kolejowych w szybkich przewozach pasażerskich (Centralna Magistrala Kolejowa Warszawa - Idzikowice - Katowice / Kraków, Kolej Dużych Prędkości "Y" na trasie Warszawa - Łódź Fabryczna - Kalisz - Wrocław - Poznań) i towarowych (Magistrala Węglowa, Magistrala Nadodrzańska, Linia Hutniczo-Szerokotorowa LHS).

- Rozbudowa kolei metropolitarnych i aglomeracyjnych (Warszawska, Krakowska, Pomorska, Wrocławska, Łódzka, Poznańska, Szczecińska, Lubelska, Rzeszowska, Olsztyńska i Górnośląska Kolej Metropolitarna) połączonych z obsługą portów lotniczych (Warszawa Modlin, Kraków Balice, Gdańsk Rębiechowo, Wrocław Strachowice, Łódź Lubinek, Poznań Ławica, Szczecin Goleniów, Lublin Świdnik, Rzeszów Jasionka, Olsztyn Szymany i Katowice Pyrzowice).

- Poprawa kolejowej obsługi turystycznej nadmorskich (Gdynia - Władysławowo - Hel, Lębork Łeba, Słupsk - Ustka, Koszalin - Mielno, Szczecin - Międzyzdroje - Świnoujście), górskich (Kraków - Zakopane / Krynica / Świnna Poręba; Jelenia Góra - Szklarska Poręba / Karpacz ) i przyjeziornych (Olsztyn / Szczytno - Mrągowo - Ełk) ośrodków turystyczno-rekreacyjnych.

- Aktywizacja w tranzytowych przewozach towarowych Linii Hutniczo-Szerokotorowej połączona z rozbudową terminali przeładunkowych w rejonie Stalowej Woli, Staszowa, Sędziszowa, Dąbrowy Górniczej (Cieśle), a po ewentualnym przedłużeniu w kierunku Kędzierzyna-Koźla trasami zlikwidowanych górnośląskich kolei piaskowych do portów śródlądowych w Gliwicach i Koźlu. 
Tab. 6. Wykaz projektów podstawowych CEF i POliś finansowanych z Funduszu Spójności, PO PW, RPO i projektów krajowych objętych KPK do 2023 r.

\begin{tabular}{|c|c|c|}
\hline Zadanie inwestycyjne & $\begin{array}{l}\text { Kwota } \\
\text { w mln zł }\end{array}$ & Program / Projekt \\
\hline ERTMS/GSM-R na liniach PLK & 2804,3 & \\
\hline Prace na alternatywnym ciągu transportowym Bydgoszcz - Trójmiasto & 1617,0 & \\
\hline Poprawa dostępu kolejowego do portu morskiego w Gdyni & 850,0 & CEF \\
\hline Poprawa dostępu kolejowego do portów morskich w Szczecinie i Świnoujściu & 639,9 & CEF \\
\hline Poprawa infrastruktury kolejowego dostępu do portu Gdańsk & 600,0 & CEF \\
\hline Projekt dynamicznej informacji pasażerskiej & 350,0 & \\
\hline Poprawa bezpieczeństwa na skrzyżowaniach linii kolejowych z drogami & 399,8 & \\
\hline Poprawa stanu technicznego obiektów inżynieryjnych & 335,0 & \\
\hline Poprawa stanu technicznego infrastruktury obsługi podróżnych & 360,0 & \\
\hline Zabudowa nowych rozjazdów kolejowych & 200,0 & \\
\hline $\begin{array}{l}\text { Modernizacja linii kolejowej E-59 na odcinku Wrocław - Poznań, etap III, odcinek Czempiń - } \\
\text { Poznań }\end{array}$ & 371,8 & Fazowany / B \\
\hline Modernizacja linii kolejowej E-30/C-E-30, odcinek Kraków - Rzeszów, etap III - Faza II & 558,9 & Fazowany / B \\
\hline Modernizacja linii kolejowej nr 8, odcinek Warszawa Okęcie - Radom (LOT: A, B, F) Faza II & 1053,4 & Fazowany / B \\
\hline Modernizacja linii kolejowej E-30, odcinek Zabrze - Katowice - Kraków, etap Ilb & 2274,8 & Fazowany / B \\
\hline Projekt poprawy dostępu kolejowego do Portu Gdańsk (most + 2-torowa linia kolejowa) - faza II & 198,0 & Fazowany / B \\
\hline Budowa łącznicy kolejowej Kraków Zabłocie - Kraków Krzemionki & 312,0 & Fazowany / B \\
\hline $\begin{array}{l}\text { Modernizacja linii kolejowej Warszawa - Łódź, etap II, Lot A - odcinek Warszawa Zachodnia - } \\
\text { Miedniewice (Skierniewice), Faza II }\end{array}$ & 109,8 & Fazowany / B \\
\hline Modernizacja linii kolejowej Warszawa - Łódź, etap II, Lot C - pozostałe roboty, Faza II & 192,5 & Fazowany / B \\
\hline $\begin{array}{l}\text { Modernizacja linii kolejowej E-75 Rail Baltica Warszawa - Białystok - granica z Litwą, etap I, odcinek } \\
\text { Warszawa Rembertów - Zielonka - Tłuszcz (Sadowne) Faza II }\end{array}$ & 560,3 & Fazowany / B \\
\hline Prace na linii kolejowej C-E-59 na odcinku Wrocław Brochów / Grabiszyn - Głogów & 500,0 & $\mathrm{P}$ \\
\hline $\begin{array}{l}\text { Prace na podstawowych ciągach pasażerskich (E-30 i E-65) na obszarze Śląska, etap I: linia E-65 na } \\
\text { odc. Będzin - Katowice - Tychy - Czechowice-Dziedzice - Zebrzydowice - prace przygotowawcze }\end{array}$ & 39,9 & $\mathrm{CEF} / \mathrm{P}$ \\
\hline Prace na linii kolejowej E-59 na odcinku Poznań Główny - Szczecin Dąbie & 2234,0 & CEF / P \\
\hline Prace na linii kolejowej nr 8, odcinek Warka - Radom (Lot: C, D, E) & 779,9 & U \\
\hline $\begin{array}{l}\text { Prace na linii kolejowej nr } 7 \text { Warszawa Wschodnia Osobowa - Dorohusk na odcinku Warszawa - } \\
\text { Otwock - Dęblin - Lublin }\end{array}$ & 3975,5 & U \\
\hline $\begin{array}{l}\text { Prace na linii kolejowej E-59 na odcinku Wrocław - Poznań, etap IV, odcinek granica województwa } \\
\text { dolnośląskiego - Czempiń }\end{array}$ & 1544,4 & $\mathrm{CEF} / \mathrm{U}$ \\
\hline $\begin{array}{l}\text { Prace na linii E-75 na odcinku Sadowne - Czyżew wraz z robotami pozostałymi na odcinku } \\
\text { Warszawa Rembertów - Sadowne }\end{array}$ & 1032,8 & CEF / U \\
\hline Prace na linii E-75 na odcinku Czyżew - Białystok & 1694,5 & $\mathrm{CEF} / \mathrm{U}$ \\
\hline Prace na linii nr 93 na odcinku Trzebinia - Oświęcim - Czechowice-Dziedzice & 555,0 & $\mathrm{U}$ \\
\hline $\begin{array}{l}\text { Prace na liniach kolejowych nr 132, 138, 147, 161, 180, 188, 654, 655, 657, 658, } 699 \text { na odcinku } \\
\text { Gliwice - Bytom - Chorzów Stary - Mysłowice Brzezinka - Oświęcim oraz Dorota - Mysłowice } \\
\text { Brzezinka }\end{array}$ & 351,5 & \\
\hline Prace na linii średnicowej w Warszawie na odcinku Warszawa Wschodnia - Warszawa Zachodnia & 1000,0 & \\
\hline $\begin{array}{l}\text { Prace na linii kolejowej E-30 na odcinku Kraków Główny Towarowy - Rudzice wraz z dobudową } \\
\text { torów linii aglomeracyjnej }\end{array}$ & 1678,5 & CEF / B \\
\hline $\begin{array}{l}\text { Prace na linii kolejowej C-E-65 na odcinku Chorzów Batory - Tarnowskie Góry - Karsznice - } \\
\text { Inowrocław - Bydgoszcz - Maksymilianowo }\end{array}$ & 1000,0 & $\mathrm{~B} / \mathrm{U}$ \\
\hline Prace na linii kolejowej nr 146 na odcinku Wyczerpy - Chorzew Siemkowice & 250,1 & $\mathrm{U}$ \\
\hline $\begin{array}{l}\text { Udrożnienie Łódzkiego Węzła Kolejowego (TEN-T), etap II, odcinek Łódź Fabryczna - Łódź Kaliska/ } \\
\text { Łódź Żabieniec }\end{array}$ & 1921,3 & u \\
\hline $\begin{array}{l}\text { Prace na liniach kolejowych nr 140,148, 157, 159, 173, 689, } 691 \text { na odcinku Chybie - Żory - Rybnik } \\
\text { - Nędza / Turze }\end{array}$ & 503,2 & $u$ \\
\hline $\begin{array}{l}\text { Poprawa przepustowości linii kolejowej E-20 na odcinku Warszawa - Kutno, etap I: Prace na linii } \\
\text { kolejowej nr } 3 \text { na odcinku Warszawa - granica LCS Łowicz }\end{array}$ & 88,7 & $u$ \\
\hline Prace na linii kolejowej nr 202 na odcinku Gdynia Chylonia - Słupsk & 2000,0 & \\
\hline Prace na linii kolejowej nr 1 na odcinku Częstochowa - Zawiercie & 501,7 & $\mathrm{U}$ \\
\hline Prace na linii kolejowej nr 289 na odcinku Legnica - Rudna Gwizdanów & 249,8 & $u$ \\
\hline
\end{tabular}




\begin{tabular}{|c|c|c|}
\hline Zadanie inwestycyjne & $\begin{array}{c}\text { Kwota } \\
\text { w mln zł }\end{array}$ & Program / Projekt \\
\hline Poprawa przepustowości linii kolejowej E-20 na odcinku Warszawa - Mińsk Maz., etap I & 9,3 & \\
\hline $\begin{array}{l}\text { Prace na linii obwodowej w Warszawie (odc. Warszawa Gołąbki / Warszawa Zachodnia - Warszawa } \\
\text { Gdańska) }\end{array}$ & 344,1 & $\mathrm{CEF} / \mathrm{U}$ \\
\hline $\begin{array}{l}\text { Prace na liniach kolejowych nr 14, } 811 \text { na odcinku Łódź Kaliska - Zduńska Wola - Ostrów Wlkp., } \\
\text { etap I: Łódź Kaliska - Zduńska Wola }\end{array}$ & 480,1 & $\mathrm{CEF} / \mathrm{U}$ \\
\hline $\begin{array}{l}\text { Prace na linii kolejowej E-20 na odcinku Warszawa - Poznań - pozostałe roboty, odcinek } \\
\text { Sochaczew - Swarzędz }\end{array}$ & 2610,8 & CEF / U \\
\hline Prace na linii kolejowej nr 6 na odcinku Białystok - Sokółka - Kuźnica Białostocka (granica państwa) & 187,2 & \\
\hline Prace na linii kolejowej Warszawa Włochy - Grodzisk Mazowiecki (linia nr 447) & 359,6 & CEF / U \\
\hline Infrastrukturalne projekty aglomeracyjne finansowane z Funduszu Spójności & 1089,8 & \\
\hline $\begin{array}{l}\text { Poprawa bezpieczeństwa na CMK poprzez likwidację przejazdów w poziomie szyn w km } 127 \text { i } 147 \\
\text { oraz budowę skrzyżowań dwupoziomowych }\end{array}$ & 17,5 & CEF \\
\hline Prace na liniach nr 153, 199, 681, 682, 872 na odcinku Toszek Północ - Rudziniec - Stare Koźle & 282,7 & \\
\hline Prace na linii kolejowej nr 38 na odcinku Ełk - Korsze wraz z elektryfikacją & 578,5 & $\mathrm{P}$ \\
\hline Elektryfikacja linii kolejowych nr 274, 278 na odcinku Węgliniec - Zgorzelec & 100,0 & CEF / B \\
\hline $\begin{array}{l}\text { Budowa nowej linii kolejowej Podłęże - Szczyrzyc - Tymbark/Mszana Dolna oraz modernizacja } \\
\text { istniejącej linii kolejowej nr } 104 \text { Chabówka - Nowy Sącz - Etap II }\end{array}$ & 3064,0 & 685,5 \\
\hline Rezerwa Funduszu Spójności & 2354,3 & \\
\hline Razem Fundusz Spójności na lata 2014-2020 & 46585,8 & \\
\hline Prace na liniach nr 68, 565 na odcinku Lublin - Stalowa Wola Rozwadów wraz z elektryfikacją & 462,6 & $\mathrm{PO} \mathrm{PW} / \mathrm{U}$ \\
\hline Prace na liniach nr 25, 74, 78 na odcinku Stalowa Wola - Tarnobrzeg/Sandomierz - Ocice /Padew & 345,4 & $\mathrm{PO} \mathrm{PW} / \mathrm{U}$ \\
\hline Prace na linii kolejowej nr 32 na odcinku Białystok - Bielsk Podlaski (Lewki) & 51,2 & $\mathrm{PO} \mathrm{PW} / \mathrm{P}$ \\
\hline Prace na linii kolejowej nr 25 na odcinku Skarżysko-Kamienna - Sandomierz & 339,1 & $\mathrm{PO} \mathrm{PW} / \mathrm{P}$ \\
\hline Prace na linii kolejowej nr 31 na odcinku gr. województwa - Czeremcha - Hajnówka & 173,8 & PO PW / P \\
\hline Prace na linii kolejowej nr 52 Lewki - Hajnówka & 86,1 & $\mathrm{PO} \mathrm{PW} / \mathrm{P}$ \\
\hline Prace na linii kolejowej nr 216 na odcinku Działdowo - Olsztyn & 237,4 & $\mathrm{PO} \mathrm{PW} / \mathrm{U}$ \\
\hline Prace na linii kolejowej nr 219 na odcinku Ełk - Szczytno & 326,7 & $\mathrm{PO} \mathrm{PW} / \mathrm{U}$ \\
\hline Rezerwa PO PW & 72,0 & PO PW \\
\hline Razem Program Operacyjny Polska Wschodnia na lata 2014-2020 & 2094,3 & \\
\hline $\begin{array}{l}\text { Rewitalizacja linii kolejowej nr } 274 \text { na odcinku Jelenia Góra - Zgorzelec wraz z łącznicą kolejową } \\
\text { linia nr } 778 \text { Etap I }\end{array}$ & 85,0 & Dolnośląskie \\
\hline $\begin{array}{l}\text { Rewitalizacja linii kolejowej nr } 292 \text { Jelcz Miłoszyce - Wrocław Sołtysowice w celu przywrócenia } \\
\text { przewozów pasażerskich we WrOF }\end{array}$ & 54,7 & Dolnośląskie \\
\hline Rewitalizacja linii kolejowej nr 137 na odcinku Legnica - Dzierżoniów & 65,0 & Dolnośląskie \\
\hline $\begin{array}{l}\text { Rewitalizacja linii kolejowej nr } 285 \text { na odcinku Wrocław Gł. - Świdnica Przedmieście wraz z linią nr } \\
771 \text { Świdnica Przedmieście - Świdnica Miasto }\end{array}$ & 135,0 & Dolnośląskie \\
\hline Przebudowa linii kolejowej nr 285 na odcinku Świdnica Kraszowice - Jedlina Zdrój & 87,9 & Dolnośląskie \\
\hline Prace na linii kolejowej nr 208 na odcinku Grudziądz - Tuchola - granica województwa & 37,6 & Kujawsko-pomorskie \\
\hline Rewitalizacja linii kolejowej nr 207 na odcinku Toruń Wschodni - Chełmża & 43,4 & Kujawsko-pomorskie \\
\hline Rewitalizacja linii kolejowych nr 208 i 33 na odcinku Grudziądz - Brodnica & 56,5 & Kujawsko-pomorskie \\
\hline Rewitalizacja linii kolejowej nr 207 na odcinku Grudziądz - granica województwa & 41,6 & Kujawsko-pomorskie / U \\
\hline Poprawa stanu infrastruktury do obsługi pasażerów & 43,6 & Kujawsko-pomorskie \\
\hline Rewitalizacja linii kolejowej nr 30 na odcinku Lubartów - Parczew & 91,4 & Lubelskie \\
\hline Rewitalizacja linii kolejowej nr 203 na odcinku Krzyż - Gorzów Wielkopolski & 100,0 & Lubuskie \\
\hline Modernizacja linii nr 358 Zbąszynek - Gubin na odcinku Zbąszynek - Czerwieńsk - II etap & 69,8 & Lubuskie \\
\hline Rewitalizacja linii kolejowej nr 16 Łódź Widzew - Kutno na odcinku Zgierz - Ozorków & 135,0 & Łódzkie \\
\hline Elektryfikacja odcinka linii nr 25 Tomaszów Maz. - Opoczno & 40,0 & Łódzkie \\
\hline Rewitalizacja linii nr 117 odc. Kalwaria Lanckorona - Wadowice - gr. województwa & 121,8 & Małopolskie \\
\hline $\begin{array}{l}\text { Budowa odcinka linii kolejowej od stacji Modlin do Mazowieckiego Portu Lotniczego (MPL) } \\
\text { Warszawa / Modlin oraz budowa stacji kolejowej }\end{array}$ & 120,0 & Mazowieckie \\
\hline Rewitalizacja linii kolejowej nr 33 Kutno - Płock & 100,8 & Mazowieckie \\
\hline Modernizacja linii kolejowej nr 35 na odcinku Ostrołęka - Chorzele & 137,5 & Mazowieckie \\
\hline Prace na linii kolejowej nr 28 Wieliszew - Zegrze & 17,0 & Mazowieckie \\
\hline Rewitalizacja linii kolejowej nr 287 Nysa - Opole & 104,0 & Opolskie / P \\
\hline Rewitalizacja linii kolejowych nr 301 i nr 293 na odcinku Opole - Kluczbork & 53,1 & Opolskie \\
\hline Rewitalizacja linii kolejowej nr 288 Nysa - Brzeg & 40,9 & Opolskie \\
\hline Rewitalizacja linii kolejowej nr 106 na odcinku Boguchwała - Czudec & 42,5 & Podkarpackie / P \\
\hline
\end{tabular}




\begin{tabular}{|c|c|c|}
\hline Zadanie inwestycyjne & $\begin{array}{c}\text { Kwota } \\
\text { w mln zł }\end{array}$ & Program / Projekt \\
\hline Rewitalizacja linii kolejowej nr 108 na odcinku Jasło - Nowy Zagórz & 220,2 & Podkarpackie \\
\hline Rewitalizacja linii kolejowej nr 25 na odcinku Padew - Mielec - Dębica & 102,2 & Podkarpackie \\
\hline Budowa łącznicy kolejowej Jedlicze - Szebnie & 82,3 & Podlaskie \\
\hline Rewitalizacja linii kolejowej nr 59 na odcinku granica państwa - Chrzanów (szerokotorowa) & 37,0 & Podlaskie \\
\hline Rewitalizacja linii kolejowej nr 57 na odcinku Kuźnica Białostocka - Geniusze (szerokotorowa) & 90,0 & Podlaskie \\
\hline Rewitalizacja linii kolejowej nr 36 na odcinku Łapy - Śniadowo - gr. województwa & 41,3 & Podlaskie \\
\hline Rewitalizacja linii kolejowej nr 49 na odcinku Śniadowo - Łomża & 35,9 & Podlaskie \\
\hline Prace na linii nr 32 odc. Lewki - Czeremcha & 25,0 & Podlaskie \\
\hline Rewitalizacja linii kolejowej nr 405 odcinek granica województwa - Słupsk - Ustka & 203,0 & Pomorskie / U \\
\hline Rewitalizacja linii kolejowej nr 207 odcinek granica województwa - Malbork & 217,8 & Pomorskie / U \\
\hline Rewitalizacja linii kolejowej nr 229 odcinek Lębork - Łeba & 170,0 & Pomorskie \\
\hline Budowa linii kolejowej nr 582 Czarnca - Włoszczowa Płn. & 42,8 & Świętokrzyskie \\
\hline $\begin{array}{l}\text { Budowa zintegrowanego systemu komunikacyjnego wraz z tunelem pod torami } \\
\text { w obrębie dworca kolejowego stacji Skarżysko Kamienna }\end{array}$ & 43,6 & Świętokrzyskie \\
\hline Modernizacja istniejących i budowa nowych przystanków kolejowych & 31,2 & Świętokrzyskie \\
\hline Rewitalizacja linii kolejowej nr 221 Gutkowo - Braniewo & 231,2 & Warmińsko-mazurskie \\
\hline Modernizacja linii kolejowej nr 354 Poznań Główny POD - Chodzież - Piła Główna & 500,0 & Wielkopolskie / U \\
\hline Rewitalizacja linii kolejowej nr 210 na odcinku Szczecinek - Runowo Pomorskie & 177,8 & Zachodnio-pomorskie \\
\hline Razem Regionalne Programy Operacyjne na lata 2014-2020 & 4667,0 & \\
\hline $\begin{array}{l}\text { Rewitalizacja linii kolejowej nr } 131 \text { Chorzów Batory - Tczew, odcinek Bydgoszcz Główna - Zduńska } \\
\text { Wola - Chorzów Batory }\end{array}$ & 59,0 & Krajowy / U \\
\hline Modernizacja linii nr 273 na odcinku Głogów - Zielona Góra - Rzepin - Dolna Odra & 72,2 & Krajowy / U \\
\hline Rewitalizacja linii nr 61 i 572 na odcinku Włoszczowa Północ - Częstochowa Stradom & 16,5 & krajowy \\
\hline Prace na linii kolejowej nr 169 na odcinku Tychy - Orzesze Jaśkowice & 37,7 & krajowy \\
\hline $\begin{array}{l}\text { Wymiana nawierzchni na odcinku Kórnik - Poznań Główny wraz z przebudową mostu stalowego } \\
\text { na rzece Warcie }\end{array}$ & 36,8 & krajowy \\
\hline $\begin{array}{l}\text { Budowa łącznicy kolejowej wraz z przystankiem osobowym w ciągu linii kolejowych nr } 97 \text { Skawina } \\
\text { - Żywiec i nr } 98 \text { Sucha Beskidzka - Chabówka }\end{array}$ & 23,3 & krajowy / B \\
\hline Modernizacja stacji Libiąż na linii kolejowej nr 93 Trzebinia - Zebrzydowice & 27,8 & krajowy \\
\hline Modernizacja linii kolejowej nr 4 - Centralna Magistrala Kolejowa & 930,8 & krajowy / B \\
\hline Modernizacja linii kolejowej nr 91 Rzeszów - granica & 122,1 & krajowy \\
\hline Modernizacja linii nr 274 Wrocław - Zgorzelec na odcinku Wrocław - Jelenia Góra & 72,8 & Krajowy / B \\
\hline $\begin{array}{l}\text { Prace na liniach nr 353, 206, } 544 \text { Poznań Wschód - Dziarnowo - Inowrocław Rąbinek oraz Zamków } \\
\text { - Borysławice }\end{array}$ & 137,2 & Krajowy / B \\
\hline Modernizacja linii kolejowej nr 8 Radom - Kielce & 37,6 & krajowy \\
\hline Prace na linii nr 353 na odcinku Jabłonowo Pom. - łława - Olsztyn - Korsze & 199,3 & Krajowy / U \\
\hline Modernizacja linii Rzeszów - Warszawa przez Kolbuszową etap II & 120,8 & krajowy \\
\hline Przebudowa infrastruktury obsługi podróżnych na stacjach i przystankach & 210,9 & krajowy \\
\hline Poprawa bezpieczeństwa i likwidacja zagrożeń eksploatacyjnych na sieci kolejowej & 734,7 & krajowy \\
\hline $\begin{array}{l}\text { Zwiększenie przepustowości wybranych linii kolejowych poprzez optymalizację urządzeń } \\
\text { sterowania ruchem kolejowym i układów stacyjnych }\end{array}$ & 277,9 & krajowy \\
\hline Prace na linii nr 7 na odcinku Lublin - Dorohusk & 100,0 & krajowy \\
\hline $\begin{array}{l}\text { Poprawa stanu technicznego infrastruktury kolejowej w rejonach przejść granicznych, w tym toru } \\
\text { szerokiego }\end{array}$ & 245,1 & krajowy \\
\hline Udrożnienie podstawowych ciągów wywozowych z Górnego Śląska & 2595,3 & Krajowy / U \\
\hline Udrożnienie podstawowych ciągów wywozowych z Dolnego Śląska & 951,8 & krajowy \\
\hline Zwiększenie kolejowej dostępności regionów atrakcyjnych turystycznie & 1250,0 & krajowy \\
\hline $\begin{array}{l}\text { Zwiększenie dostępności magistrali E-20 i C-E-20 poprzez poprawę stanu technicznego } \\
\text { przyległych linii kolejowych }\end{array}$ & 958,9 & krajowy \\
\hline $\begin{array}{l}\text { Budowa nowej linii Podłęże - Szczyrzyc - Tymbark/Mszana Dolna oraz modernizacja istniejącej linii } \\
\text { nr } 104 \text { Chabówka - Nowy Sącz - Etap I: prace przygotowawcze }\end{array}$ & 311,7 & krajowy \\
\hline Razem projekty krajowe & 9997,9 & krajowy \\
\hline
\end{tabular}

Uwagi: B - budowa, U - umowa, P - projekt / przetarg.

Źródło: Krajowy Program Kolejowy do 2023 r., Infrastruktura kolejowa zarządzana przez PKP PLK, listopad 2016 r. 


\section{Piśmiennictwo}

Koziarski S., 2014, Polska w systemie transportowym Unii Europejskiej. Inwestycje infrastrukturalne, Uniwersytet Opolski, Studia i Monografie, nr 512, Opole, ss. 235.

Krajowy Program Kolejowy do 2023 r., Infrastruktura kolejowa zarządzana przez PKP PLK, listopad 2016 r., Ministerstwo Infrastruktury i Budownictwa, Warszawa.

Realizacja Wieloletniego Programu Inwestycji Kolejowych, Informacja o wynikach kontroli, 16.12.2016 r., Departament Infrastruktury NIK, Raport NIK, Warszawa.

Transport - wyniki działalności w 2016 r., 2017, GUS, Warszawa. www.rynek-kolejowy.pl [19.04.2017]

www.skyscrapercity.com [22.03.2017] 